\title{
Gas migration pathways and slope failures in the Danube Fan, Black Sea
}

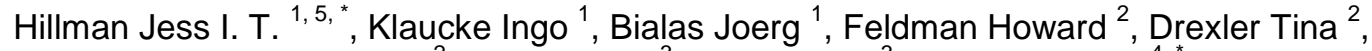 \\ Awwiller David ${ }^{2}$, Atgin Orhan ${ }^{3}$, Cifci Gunay ${ }^{3}$, Badhani Shray ${ }^{4, *}$
}

${ }^{1}$ GEOMAR Helmholtz Ctr Ocean Res, Wischhofstr 1-3, D-24148 Kiel, Germany.

2 ExxonMobil Upstream Res, 22777 Springwoods Village Pkwy, Spring, TX 77389 USA.

3 Dokuz Eylul Univ, Inst Marine Sci \& Technol, Haydar Aliyev Blvd 100, TR-35340 Izmir, Turkey.

${ }^{4}$ Ctr Bretagne ZI Pointe Diable, Lab Aleas Geol \& Dynam Sedimentaire, CS 10070, F-29280 Plouzane, France.

${ }^{5}$ GNS Sci, 1 Fairway Dr, Avalon 5010, New Zealand.

* Corresponding authors : Jess I. T. Hilman, email address : j.hillman@gns.cri.nz ; Shray Badhani, email address : Shray.Badhani@ifremer.fr

\begin{abstract}
:
A large geophysical dataset, including bathymetry, and 2D and 3D P-cable seismic data, revealed evidence of numerous gas flares near the S2 Canyon in the Danube Fan, northwestern Black Sea. This dataset allows us to investigate potential relationships between gas migration pathways, gas vents observed at the seafloor and submarine slope failures. Vertical gas migration structures as revealed in the seismics appear to be concentrated near submarine slope failure structures. Where these seismically defined features extend upwards to the seafloor, they correlate with the location of gas flares. However, not all these structures reach the seafloor, in some cases because they are capped by overlying sediments. A strong correlation is inferred between gas migration pathways, heterogeneous mass transport deposits and contacts between adjacent units of contrasting lithology. Although missing age constrains prevent a final judgement, we discuss the potential relationship between submarine slope failures and gas migration in order to determine if gas migration is a precursor to failure, or if the presence of slope failures and associated mass transport deposits facilitates the migration of gas. Our observations indicate that lithological heterogeneity, mass transport deposits and minor sediment deformation control gas migration pathways and the formation of gas chimney-like features. Gas migration is focused and gradual, resulting in gas flares where the chimney-like features extend to the seafloor, with no evidence of erosive features such as pockmarks.
\end{abstract}




\section{Highlights}

- Identify 3 groups of gas migration structures in seismic data from the Danube Fan. Migration structures related to shallow gas migration and flares at the seafloor. Gas migration is controlled by lithological heterogeneity and sediment deformation. Mass transport deposits play a role in controlling vertical migration occurrence.

Keywords : Gas migration, Chimneys, Gas hydrate, Danube Fan, Slope failure, Black Sea 
31 The Black Sea is thought to contain $96 \times 10^{9} \mathrm{~kg}$ of methane dissolved in the water, with an estimated 1$5 \times 10^{12} \mathrm{~m}^{3}$ of gas hydrates, resulting in a basin-wide flux of methane into the water column of 3.604.28 $\mathrm{Tg} \mathrm{yr}^{-1}$ (Kessler et al., 2006; Starostenko et al., 2010). Reeburgh et al. (1991) and Kessler et al. (2006) concluded that the Black Sea is the largest surface water reservoir of dissolved methane, emitting 0.066

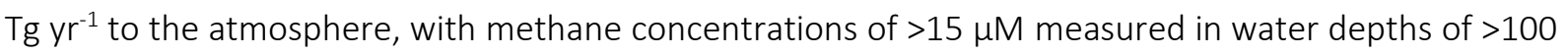
m (Pape et al., 2008). Approximately $68 \%$ of the Black Sea basin is thought to be suitable for gas hydrate formation, but evidence of hydrates in the form of bottom simulating reflections (BSRs) within the expected gas hydrate stability zone (GHSZ) has been observed in only a few areas in water depths of 600-1800 m (Lüdmann et al., 2004; Popescu et al., 2007; Popescu, 2006; Starostenko et al., 2010; Vasilev and Dimitrov, 2002; Zander et al., 2017b). The best and most widespread BSRs in the Black Sea have been imaged in the Danube Fan area (Popescu et al., 2007, 2006; Zander et al., 2017b). Outlines of the BSR distribution in the Danube Fan by Popescu et al. $(2007,2006)$ and Zander et al. $(2017 b)$ vary slightly depending on the referred data set, but are clearly separated by the Viteaz Canyon. Gas hydrates have been recovered in the Danube Delta (Riboulot et al., 2018), offshore Crimea (Bohrmann et al., 2003; Römer et al., 2012), and offshore Georgia (Heeschen et al., 2011) but without clear evidence of a BSR. These sites are associated with gas emissions (gas flares) at the seafloor (Greinert et al., 2006; Klaucke et al., 2006; Römer et al., 2012), but most gas flares in the Black Sea occur in water depths of less than 725 m, i.e. above the GHSZ (Naudts et al., 2006).

The precise mechanisms by which gas migrates from depth to reach the seafloor in the Danube Fan are still poorly understood. Understanding shallow gas migration and the potential relationship with the

51 hydrate system in this region is of interest for offshore hydrocarbon exploration due to the potential hazard of shallow gas accumulations when drilling, and also the possible connection to submarine slope

53 failures which pose a risk to seafloor infrastructure. In this study we present seismic data acquired during the R/V Maria S. Merian (MSM34) cruise of 2013-2014 (Figs. 1 and 2) to demonstrate that there 
are several settings that are conducive to gas migration in the region, including lithological contacts acting as flow pathways and vertical gas migration structures, or gas chimneys. Gas chimneys are defined as an area of low-concentration gas migrating upwards from a gas accumulation at depth (Cartwright, 2007; Gay et al., 2006; Karstens and Berndt, 2015; Koch et al., 2015). Gas chimneys act as conduits for vertical migration of fluid and/or gas and can be imaged in seismic data as anomalies characterized by distorted reflections and low velocities caused by incoherent scattering, absorption and poor stacking due to nonhyperbolic normal moveout (NMO) (Karstens and Berndt, 2015; Løseth et al., 2009; Sheriff, 2011).

There are several factors that may play a role in controlling the migration of gas through the sediments. The formation of gas chimneys and other vertical fluid flow anomalies is generally controlled by overpressure-induced hydrofracturing of overlying, low-permeability sediments (Judd and Hovland, 2007; Karstens and Berndt, 2015; Mountjoy et al., 2014). Other factors, such as faulting and deformation, lateral gas migration, formation-wide overpressure, and lithological heterogeneity may also play a role (Cartwright et al., 2007; Chenrai and Huuse, 2017; Karstens and Berndt, 2015; Nicoll, 2016; Seebeck et al., 2015). Determining how these factors interact may help us in understanding the formation history and location of gas chimneys and flares. In addition, we propose that gas accumulation due to overpressure build up may be one of the driving forces behind the development of gas flares at the seafloor. Lastly, we investigate the potential link between gas migration and slope failure events in the vicinity of a submarine canyon in the Danube Fan.

\section{Geological setting of the Danube Fan}

The Danube Fan is a fine-grained turbidite system located in the northwest Black Sea, offshore Romania (Fig. 1 and 2) and consists of a series of stacked channel-levee sequences that have built up over the last 900 ka (Popescu et al., 2001; Winguth et al., 2000; Wong et al., 1997, 1994; Zander et al., 2017b). The continental shelf here is up to $120 \mathrm{~km}$ in width, and the Danube Fan lies downslope of the shelf break (at 100 m water depth) extending down to the basin floor at depths of >2200 m (Wong et al., 1997). The channel-levee systems of the Danube Fan are characterized by erosional processes in the 
upper reaches, transitioning to depositional processes in the middle to lower slope (Feldman et al., 2017; Popescu et al., 2001). The Viteaz Canyon was the most recently active canyon in the fan during the last glacial maximum when it was connected directly to the Danube River (Popescu et al. 2001). The development of the submarine canyons that still have a bathymetric expression was initiated $\sim 22 \mathrm{ka}$, with several smaller canyons being incised prior to the formation of the main Viteaz Canyon (Winguth, 1998; Winguth et al., 2000). One such canyon is the S2 Canyon, which lies to the northeast of the Viteaz Canyon and is the focus of this study (Figs. 1 and 2). These features are classified as canyons in the upper reaches where they are incising the shelf edge and dominated by erosional processes, and channels in the outer reaches of the fan where they are dominated by depositional, aggregational processes (Popescu et al., 2001). For consistency, in this study we refer to the two features being discussed as the Viteaz Canyon and the S2 Canyon, as we are primarily concerned with the upper reaches where the canyons incise the shelf edge. The morphology of the canyons and channels in the Danube Fan is influenced by the Coriolis force-a common observation in mid- to high-latitude systems with a right deviation of flow direction in currents in the northern hemisphere (Menard, 1955)-resulting in larger levees on the western side of the canyons (right-hand to the downslope flows) relative to those to the east (Popescu et al., 2001; Zander et al., 2017b). The fan was abandoned as sea level rose at about 7,500 years bp, resulting in sediment supply being restricted to nearshore lagoons (Chepalyga, 1984; Lericolais et al., 2013; Martin and Yanko-Hombach, 2011; Panin and Popescu, 2007).

A key stratigraphic horizon in the region is the Base Neoeuxinian Sequence Boundary (BNSB), which marks the onset of activity in the Danube Fan during the last sea-level lowstand in the Black Sea (Fig. 3) (Popescu et al., 2001). The BNSB horizon has been dated at $\sim 22 \mathrm{ka}$ using ${ }^{14} \mathrm{C}$ dating of a sample recovered in core MD04-2762 during the ASSEMBLAGE 1 cruise in 2004 (Lericolais et al., 2013). This sample was recovered $\sim 150 \mathrm{~km}$ southeast of the MSM34 study area, and as such, only provides a minimum age for the BNSB. Whilst the MD04-2762 core provides a minimum age for the BNSB, the maximum age of this horizon $\sim 75$ ka can be determined using sea level curves as sea level rise prior to 75 ka prevented sedimentation in the Danube Fan (Chepalyga, 1984; Panin and Popescu, 2007). 
There are four key sedimentary facies in the Danube Fan: mass transport deposits (MTDs), channel fill sediments, lobes and levee deposits (Popescu et al., 2004). Lobes are not significant on the slope and as such are not discussed further here. The other three are characterised in seismic data as follows.

1. Mass transport deposits (MTDs), or slumps associated with slope failure events are characterised by hummocky, chaotic and irregular seismic facies, with discontinuous, low to high amplitude reflections (Popescu et al., 2004; Winguth et al., 2000; Zander et al., 2017a). These deposits are interpreted as predominantly fine-grained sediment, with occasional coarsegrained sections in some areas. Although there is some discussion in literature regarding the definition of slope failure related deposits, for the purposes of this study, all deposits associated with slope failure events are referred to as MTDs (Mulder and Alexander, 2001; Mulder and Cochonat, 1996).

2. Canyon fill sediments are associated with turbidity-current deposits within the canyons. While canyons are, by definition, erosive, they become partially infilled by such late-stage deposits because of waning turbidity current activity. These are characterised by subparallel, irregular or hummocky reflections along narrow belts with high amplitudes in seismic data (Flood et al., 1991; Konerding, 2008; Lericolais et al., 2013; Winguth et al., 2000). These sediments are predominantly coarse-grained clastics with a high proportion of sand inferred from the seismic response and similar analogs, such as the Amazon Fan (Flood et al., 1991).

3. Levee deposits are extensive across the Danube Fan, with the Viteaz Levee sediments extending across much of the study area. Levees are predominantly composed of finely-laminated, finegrained spill-over turbidites. They may also contain occasional thin, sand-rich intervals that can act as permeable pathways. These are characterised in the seismic data by parallel to convergent, laterally continuous reflections of low to medium amplitudes with an overall wedge-shaped geometry (Popescu et al., 2001; Winguth et al., 2000; Wong et al., 1997).

Gas flares in the water column have been recorded in over 5000 locations in the Black Sea and range from seeps related to deep seated mud volcanoes (Greinert et al., 2006) to widespread seepage in water 
depths shallower than the upper limit of the gas hydrate stability zone (Egorov et al., 2011, 2003; Naudts et al., 2006; Römer et al., 2012; Starostenko et al., 2010). Few gas flares have been observed from within the gas hydrate stability zone (Klaucke et al., 2006; Römer et al., 2012). Upward migration of gas through the sedimentary column is typically associated with structural or lithological contacts, which facilitate the movement of gas and can be imaged in seismic data as so-called gas chimneys, (Bello et al., 2017; Heggland, 2005). It has been suggested that flares in the Black Sea may be aligned along faults, as such structural features commonly act as conduits for fluid and/or gas flow (Popescu et al., 2007). In many cases, there appears to be a direct correlation, based on seismic observations, between the distribution of faults and the occurrence of flares (Popescu et al., 2007). However, they are also observed in the absence of fault systems, frequently in the vicinity of submarine slope failures and canyons (Kutas et al., 2004; Starostenko et al., 2010), or they can be aligned along the crest of submarine ridges (Naudts et al., 2006). Previous studies show that the Viteaz Canyon is located above the presumed offshore position of the Peceneaga-Camena fault; a feature which could act as a migration pathway for gas (Popescu et al., 2004; Winguth et al., 2000).

Gas venting in the Black Sea and other areas is commonly observed in conjunction with other seafloor features such as mud volcanoes, pockmarks, bacterial mats and the precipitation of authigenic carbonates (Bohrmann et al., 2003; Gay et al., 2007; Judd and Hovland, 2007; Kessler et al., 2006; Suess, 2014). Authigenic carbonates have been observed in the northwest Black Sea in the vicinity of seep sites in water depths of 230-1738 m (Mazzini et al., 2004; Peckmann et al., 2001; Starostenko et al., 2010). The origin of gas in this region is not well constrained, and previous studies have shown evidence of both thermogenic and biogenic sources in the Black Sea region (Olaru-Florea et al., 2014; Starostenko et al., 2010). Data from gas seeps and sediment cores in the northwest region show that the composition of the gas in this area is $>99 \%$ methane (Popescu et al., 2006; Zander et al., 2017b). 


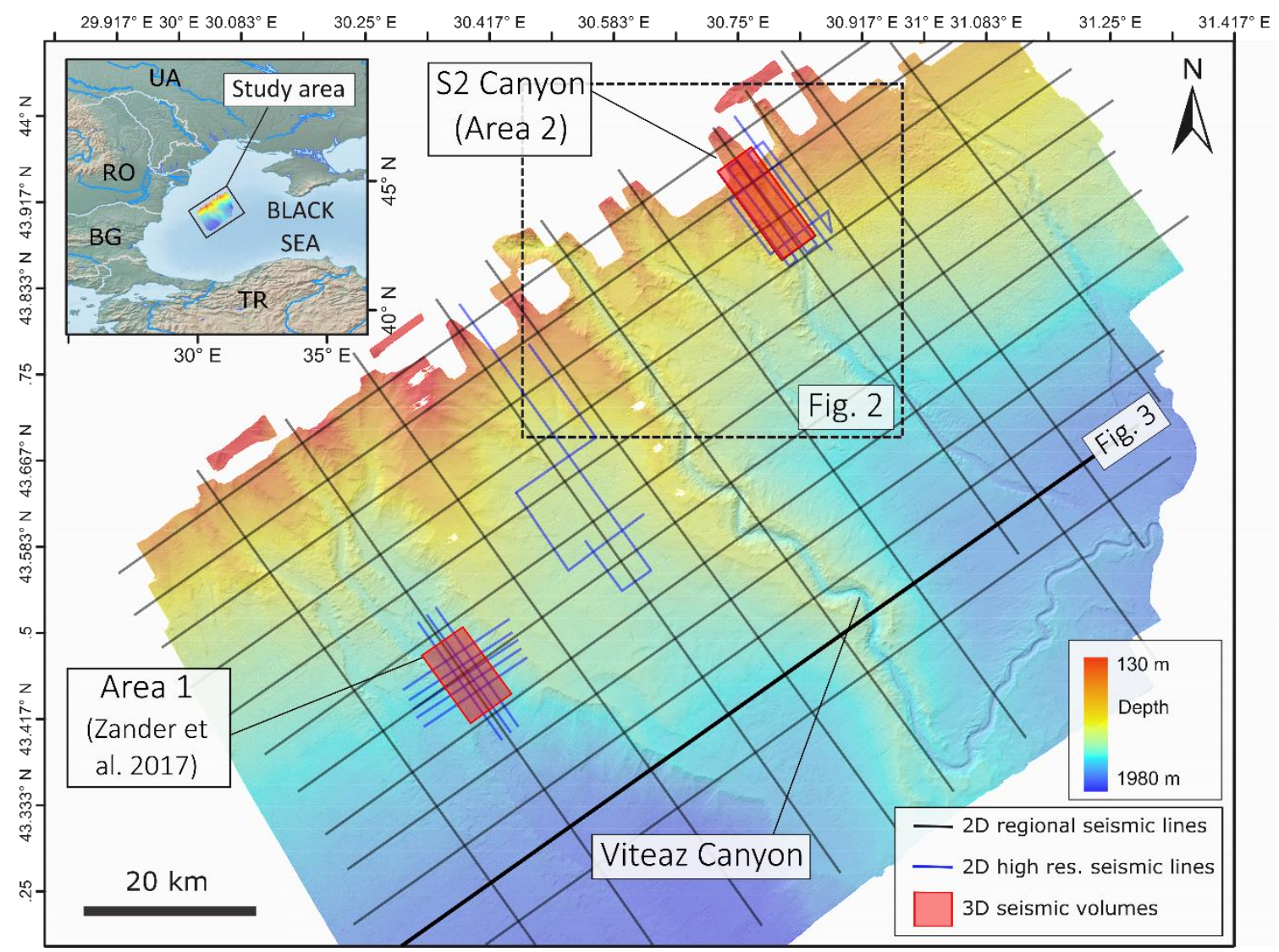

Figure 1 Map of the Danube Fan study area showing the location of the full dataset acquired during the MSM34 cruise. The focus of this paper is the S2 Canyon region in Area 2 (see Fig. 2). Inset: Location of the study area in the northwestern Black Sea. $R O=$ Romania, $T R=$ Turkey, $B G=$ Bulgaria, $U A=$ Ukraine. 


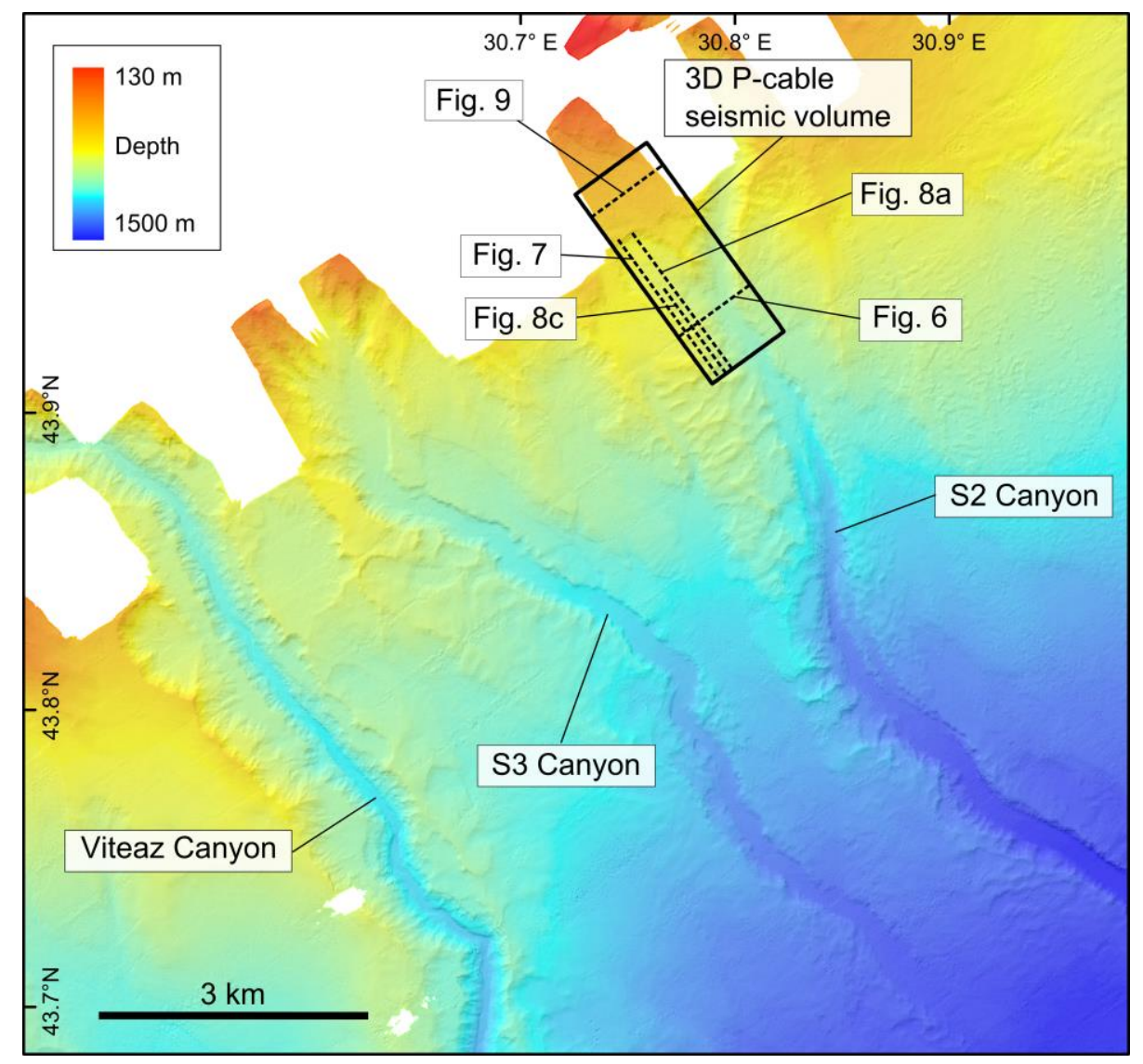

Figure 2 Map of the Danube Fan study area. The location of seismic lines included in this paper is indicated by the black dashed lines.

\section{Gas migration pathways}

Evidence of gas migration through the sedimentary column can be observed in seismic data in the form of enhanced amplitude seismic reflections associated with the presence of free gas in the sediments (Bünz and Mienert, 2004; Ecker et al., 2000; Hornbach et al., 2003; Max and Johnson, 2014). Free gas in sediments scatters acoustic energy, resulting in the disturbance of seismic reflections, an effect known as acoustic turbidity (Judd and Hovland, 2007; Popescu et al., 2007). Where gas content is high, turbidity may fade out to complete 'blanking' where sediments appear to be acoustically impenetrable (Popescu et al., 2007; Yun et al., 2005). Such features are commonly associated with anomalously high-amplitude enhanced reflections or bright spots, which result from high concentrations of free gas trapped in the sediments (Andreassen et al., 2007; Gorman et al., 2002; Karstens and Berndt, 2015). Such accumulations of free gas result in increased impedance contrast with inverted reflectivity across horizons due to the anomalously low velocity, and low impedance, of gas bearing sediments (Popescu 
et al., 2007). Gas chimneys are common in the Black Sea. On the inner shelf these features tend to terminate against a major unconformity which is interpreted as Oligocene to Upper Miocene in age (Gillet et al., 2003; Popescu et al., 2007). On the outer shelf these chimneys may reach the seafloor, resulting in active venting and gas flare formation at the seafloor (Popescu et al., 2007). This is thought to be a function of the permeability of the base of the Miocene sediments, and may also be related to increased localized gas supply as some chimneys are associated with known hydrocarbon fields (Popescu et al., 2007).

In addition to supplying gas to flares, gas migration in the subsurface is thought to have played a role in the formation of submarine slope failures (Mclver, 1982). Such failures are also found along the shelf break in the Danube Fan (Ker and Riboulot, 2015). Gas hydrates have frequently been linked to submarine slope failures, and it has been proposed that dissociation of hydrates following a shift in the GHSZ due to sea level lowering or seafloor warming may be a factor in slope failure events through generating overpressure and causing sediment destabilisation (Crutchley et al., 2007; Dondurur et al., 2013; Horozal et al., 2017; Li et al., 2016; Mountjoy et al., 2014; Sun et al., 2017). In addition, there is some debate regarding the impact that the presence of gas hydrates has on the stability of sediments. Some studies propose that the presence of gas hydrates in sediments may reduce the stability of slopes as a result of enhanced creep behaviour and high strain-dependence, as demonstrated in laboratory experiments of hydrate-bearing sediments (Handwerger et al., 2017; Mountjoy et al., 2014). Others propose that hydrates act as a cement, strengthening the sediment and thereby reducing slope failure occurrence (Winters et al., 2007; Yoneda et al., 2016). A recent paper by Elger et al. (2018) suggests that overpressure at the base of hydrate stability results in the formation of pipes, which transfer overpressure to shallow depth and contribute to destabilization of a slope.

\section{Data and methods}

During the MSM34 cruise, multibeam bathymetry data, sub-bottom profiler data, regional 2D seismic lines, high resolution 2D lines, and high resolution 3D P-cable seismic volume were acquired (Figs. 1 and 2) (Bialas et al., 2014). A grid of regional 2D multichannel seismic profiles was acquired as 
reconnaissance data across the entire Danube Fan. A high-resolution set of 2D multichannel seismic lines and a 3D multichannel seismic cube were acquired across a slope failure structure next to the S2 Canyon, hereafter referred to as the S2 slump. Multibeam bathymetry data were acquired using a 12 $\mathrm{kHz}$, hull mounted Simrad ${ }^{\circledR}$ EM122 multibeam echosounder. Bathymetry data were processed onboard using MB-systems ${ }^{\circledR}$ and gridded at a resolution of $25 \mathrm{~m} \times 25 \mathrm{~m}$. Sub-bottom profiler data were acquired using an Atlas Parasound PS70 hull mounted parametric echosounder system. The system operated with primary frequencies of 18 and $22 \mathrm{kHz}$ resulting in $4.0 \mathrm{kHz}$ secondary (parametric) signal and a beam width of $4.5-5.0^{\circ}$. The parametric frequency was used to image shallow subsurface structures and stratigraphy, with a maximum penetration of 200 ms TWT. During the second leg of the cruise (MSM342) the lower primary frequency ( $18 \mathrm{kHz}$ ) was used for water column imaging to detect gas flares.

\section{Seismic data acquisition}

The acquisition parameters for the three seismic data types acquired during the MSM34 cruise are summarised in Table 1.

Table 1 Summary of acquisition parameters for seismic surveys included in this study (Fig. 1). Nominal vessel speed of 3.5 knots.

\begin{tabular}{|c|c|c|c|}
\hline & $2 \mathrm{D}$ regional lines & 2D high resolution lines & 3D P-cable volume \\
\hline Source & $\begin{array}{l}45 \mathrm{in}^{3} / 45 \mathrm{in}^{3} \mathrm{Gl} \text { gun, shot } \\
\text { interval } 18.75 \mathrm{~m} \text {, source } \\
\text { depth } 2 \mathrm{~m}\end{array}$ & $\begin{array}{l}45 \mathrm{in}^{3} / 45 \mathrm{in}^{3} \mathrm{Gl} \text { gun, shot } \\
\text { interval of } 3 \mathrm{~s} \text {, source depth } \\
2 \mathrm{~m}\end{array}$ & $\begin{array}{l}45 \mathrm{in}^{3} / 45 \mathrm{in}^{3} \mathrm{Gl} \text { gun, shot } \\
\text { interval of } 3 \mathrm{~s} \text {, source depth } \\
2 \mathrm{~m}\end{array}$ \\
\hline Streamer & $\begin{array}{l}\text { HydroScience SeaMUX } \\
\text { Digital-bidirectional, } 1050 \mathrm{~m} \\
\text { long, } 168 \text { channels, } 6.25 \mathrm{~m} \\
\text { group interval, } 8 \\
\text { hydrophones per group. } \\
\text { Record length } 45 \mathrm{~s} \text { max. } \\
\text { Streamer depth } 4 \mathrm{~m} .\end{array}$ & $\begin{array}{l}225 \mathrm{~m} \text { long, } 144 \text { channel } \\
\text { streamer. Vibration } \\
\text { isolation section of } 25 \mathrm{~m} \text {, } \\
55 \mathrm{~m} \text { tow cable and } 19 \\
\text { active sections of } 12.5 \mathrm{~m} \\
\text { length. Total active length } \\
\text { of } 237.5 \mathrm{~m} \text {. }\end{array}$ & $\begin{array}{l}\text { Streamer depth } 2 \text { m. } 20 \\
\text { streamers towed in parallel, } \\
\text { active sections of } 12.5 \mathrm{~m} \\
\text { length, } 8 \text { channels per } \\
\text { section. }\end{array}$ \\
\hline $\begin{array}{l}\text { Data } \\
\text { acquired }\end{array}$ & $2114 \mathrm{~km}$ & $110 \mathrm{~km}$ & $30 \mathrm{~km}^{2}$ \\
\hline
\end{tabular}

\section{$\underline{2 D \text { seismic data processing }}$}

Processing of the regional 2D seismic data consisted of correction of the navigation data, signal- 
processing. The regional seismic lines have a CDP spacing of $3.12 \mathrm{~m}$ and a centre frequency of $70 \mathrm{~Hz}$.

213 The high resolution seismic lines have a CDP spacing of $1.5625 \mathrm{~m}$, with a centre frequency of $130 \mathrm{~Hz}$

214 (Bialas et al., 2014; Zander et al., 2017b). The streamers used for the high resolution seismic lines are too short for semblance analysis. The velocity information for the regional seismic profiles was therefore extrapolated to the high-resolution data. Both data types were converted from time to depth domain using the velocity information derived from the regional seismic lines and cross-checked with P-wave velocities from ocean bottom seismometers that were available in the study area (Bialas et al., 2014; Zander et al., 2017b).

\section{$\underline{P \text {-cable 3D seismic data processing }}$}

Processing of the 3D seismic data included shot and receiver repositioning, shot based signal processing, a low-cut frequency filter of $28 \mathrm{~Hz}$, a 3D marine cable filter (3D FK-dip-filt) and lastly, trace balancing. The data was then binned to a grid of $3.125 \times 3.125 \mathrm{~m}$ and stacked with a fairly averaged NMO, followed by a post-stack trace interpolation. Post stack time-migration was conducted using an extended 3D Stolt migration followed by a 2-pass frequency domain (residual) migration inline-crossline. This was done using a simple velocity model with a water velocity of $1482 \mathrm{~m} / \mathrm{s}$. The 3D volume was then depth converted using a pseudo-3D depth variant velocity model constructed using ocean bottom seismometer (OBS) data acquired during the MSM34 cruise.

\section{Seismic and sequence stratigraphic interpretation}

Both the 2D and 3D seismic data were loaded into IHS Kingdom ${ }^{\circledR}$ for the interpretation of key horizons and structures. The 2D seismic data acquired during MSM34 were used to map out regional stratigraphic horizons across the Danube submarine fan complex to provide relative age constraints for the development of the S2 channel-levee complex, and the S2 slump. Interpretation of the BNSB surface was based on the location of the sequence boundary as per Popescu et al. (2001) and modified based on the new seismic data available in this study and at ExxonMobil Upstream Research Company (EMURC). 


\section{Results}

238 The key stratigraphic horizons and units identified in the seismics are summarized in Table 2 and Figs. 3

and 4. In addition to the key lithological and stratigraphic units, a distinct BSR was identified in the 2D

and 3D seismic data across the Danube Fan. In some areas of the fan the BSR is characterized as a clear

reflection that is phase-reversed relative to the seafloor, roughly mimics seafloor topography and cross-

cuts strata. However, in the vicinity of the S2 Canyon in the 3D seismic volume the BSR is characterized

seafloor, creating a distinct boundary, with clear phase reversal of cross-cutting reflections (Fig. 5).

\begin{tabular}{|c|c|c|}
\hline Unit & Seismic Characteristics & Extent / Location \\
\hline Viteaz Levee & $\begin{array}{l}\text { Parallel to convergent, laterally continuous } \\
\text { reflections with low to medium amplitudes. } \\
\text { Wedge shaped geometry with increased } \\
\text { thickness on the western flank of the Viteaz } \\
\text { Canyon. Interpreted as slit/clay rich sediment } \\
\text { associated with turbidity currents. Higher } \\
\text { amplitude reflections interpreted as coarse- } \\
\text { grained, sand-rich horizons. }\end{array}$ & $\begin{array}{l}\text { Located along flanks of the main } \\
\text { Viteaz Canyon at the center of the } \\
\text { Danube Fan (Figs. } 2 \text { and 3). Extends } \\
\text { across the full lateral extent of the } \\
\text { seismic dataset, thinning with } \\
\text { distance from the canyon. }\end{array}$ \\
\hline S2 Levee & $\begin{array}{l}\text { Parallel to convergent, laterally continuous } \\
\text { reflections with low amplitudes. Wedge } \\
\text { shaped unit that is generally thicker to the } \\
\text { west of the S2 Canyon. Interpreted as slit/clay } \\
\text { rich sediment associated with turbidity } \\
\text { currents. }\end{array}$ & $\begin{array}{l}\text { Located along the flanks of the } \$ 2 \\
\text { Canyon. Narrow extent laterally, } \\
\text { constrained to } \sim 7 \mathrm{~km} \text { west and } \\
\sim 4 \mathrm{~km} \text { east of the } \$ 2 \text { Canyon. }\end{array}$ \\
\hline MTD 1 & \multirow{3}{*}{$\begin{array}{l}\text { Irregular, chaotic, discontinuous reflections } \\
\text { with variable amplitudes. Interpreted as } \\
\text { predominantly fine-grained material with } \\
\text { some coarse-grained sediment, highly } \\
\text { heterogeneous across units. }\end{array}$} & $\begin{array}{l}\text { Located directly above the BNSB. } \\
\text { Extends across } \sim 3200 \mathrm{~km}^{2} \text { of the } \\
\text { Danube Fan with maximum } \\
\text { thickness between the S2 and } \\
\text { Viteaz Canyons (Fig. 3). }\end{array}$ \\
\hline MTD 2 & & $\begin{array}{l}\text { Located between the } S 2 \text { and Viteaz } \\
\text { Canyons, with maximum thickness } \\
\text { immediately west of the latter (Fig. } \\
\text { 3). Extends across } \sim 520 \mathrm{~km}^{2} \text { of the } \\
\text { fan. }\end{array}$ \\
\hline $\begin{array}{l}\text { MTD } 3 \\
\text { (see Fig. 9) }\end{array}$ & & $\begin{array}{l}\text { Located at the seafloor, forming the } \\
\text { 'floor' of Slump A. Average } \\
\text { thickness of the unit is } 25 \mathrm{~m} \text {. The } \\
\text { unit is not fully mapped in the } \\
\text { MSM34 seismic data. }\end{array}$ \\
\hline
\end{tabular}




\begin{tabular}{lll}
\hline & Chaotic, discontinuous reflections with variable & $\begin{array}{l}\text { Located beneath S2 Slump, } \\
\text { discontinuous when mapped out }\end{array}$ \\
MTD 4 & seismic amplitude beneath the S2 Slump scar. & $\begin{array}{l}\text { across the 3D seismic data. Base of } \\
\text { (see Fig. 5) }\end{array}$ \\
& $\begin{array}{l}\text { material with some coarse-grained sediment, } \\
\text { highly heterogeneous across units. }\end{array}$ & $\begin{array}{l}\text { the deposits is not consistently } \\
\text { imaged in the seismic data due to } \\
\text { limited signal penetration. }\end{array}$ \\
\hline
\end{tabular}

\begin{tabular}{|c|c|c|}
\hline Feature & Characteristics & Extent / Location \\
\hline Slump A & $\begin{array}{l}\text { Elongate downslope feature that extends } \\
\sim 6 \mathrm{~km} \text { upslope of the S2 slump headwall. } \\
\text { Headwall of the slump is slightly crenulated } \\
\text { and has been incised by younger canyon } \\
\text { features (Ker and Riboulot, 2015). Average } \\
\text { height of the headwall is } 10 \mathrm{~m} \text {, average width } \\
\text { is } 2.6 \mathrm{~km} \text {. }\end{array}$ & $\begin{array}{l}\text { Upslope of the S2 Slump (Figs. } 2 \\
\text { and 4), covers } \sim 20 \mathrm{~km}^{2} \text {, not fully } \\
\text { mapped in MSM34 data - extent } \\
\text { estimated from Ker and Riboulot } \\
\text { (2015). }\end{array}$ \\
\hline Slump B & $\begin{array}{l}\text { Small slump adjacent to the S2 Canyon with a } \\
\text { relatively smooth headwall. }\end{array}$ & $\begin{array}{l}\text { Southwest flank of the S2 Canyon in } \\
\text { water depths of } 540 \text { to } 650 \text { m (Figs. } \\
2 \text { and } 4 \text { ), covers } \sim 3 \mathrm{~km}^{2} .\end{array}$ \\
\hline S2 Slump & $\begin{array}{l}\text { Well defined, horseshoe shaped feature with a } \\
\text { relatively smooth headwall. Average height of } \\
\text { the headwall is } 55 \mathrm{~m} \text {, average width is } 2.2 \mathrm{~km} \text {. }\end{array}$ & $\begin{array}{l}\text { Southwest flank of the S2 Canyon in } \\
\text { water depths of } 560 \text { to } 790 \mathrm{~m} \text {, } \\
\text { downslope of Slump A and Slump B } \\
\text { (Figs. } 2 \text { and 4), covers } \sim 8 \mathrm{~km}^{2} .\end{array}$ \\
\hline
\end{tabular}

\section{Sequence Stratigraphy}

248 Based on stratigraphic interpretation of more extensive datasets available at EMURC, the BNSB has been

249 identified in the MSM34 dataset as the prominent regional unconformity at the base of the widespread

250 MTD 1 (Fig. 3). Above the BNSB, several other stratigraphic horizons were mapped across the extent of

251 the 2D seismic data, delineating 4 key stratigraphic units (Fig. 3). These are MTD 1, the levee associated

252 with the S2 Canyon, MTD 2, and the extensive levee associated with main Danube/Viteaz Canyon (Fig.

$2533)$.

254 Based on the interpreted sequence stratigraphy and the absolute age estimates presented above,

255 sedimentation rates can be calculated for the key sediment packages in the Danube Fan and these are

256 summarised in Table 3.

257 Table 3 Sedimentation rates for the Danube Fan, calculated using average unit thickness along Line 11 258 (see Fig. 3). *In the absence of core samples to establish the precise nature of the formation MTD 1, we 259 assign a nominal duration of 1 ka for the purpose of the calculation.

\begin{tabular}{|c|c|c|c|c|c|}
\hline & $\begin{array}{l}\text { Age (ka } \\
\text { BP) }\end{array}$ & $\begin{array}{l}\text { Duration } \\
\text { (ka) }\end{array}$ & $\begin{array}{c}\text { Average } \\
\text { thickness (m) }\end{array}$ & $\begin{array}{c}\text { Volume } \\
\left(\mathrm{km}^{3}\right)\end{array}$ & $\begin{array}{l}\text { Sedimentation rate } \\
(\mathrm{m} / \mathrm{ka})\end{array}$ \\
\hline
\end{tabular}




\begin{tabular}{lccccc}
\hline Viteaz Levee & $19-7.5$ & 11.5 & 170.53 & 1161.86 & 14.8 \\
\hline S2 Levee & $21-19$ & 2 & 47.35 & 5.50 & 23.68 \\
\hline MTD 1 & $22-21$ & $<1^{*}$ & 239.19 & 596.32 & 239.19 \\
\hline
\end{tabular}

\section{$\underline{\text { Gas flares }}$}

During the MSM34 cruise several acoustic anomalies in the water column were imaged in the high

frequency sub-bottom profiler data (Fig. 5). Most of these occur at approximate water depths of

$\sim 665 \mathrm{~m}$, which correlates to the calculated top of the GHSZ. Several of the flares were observed during

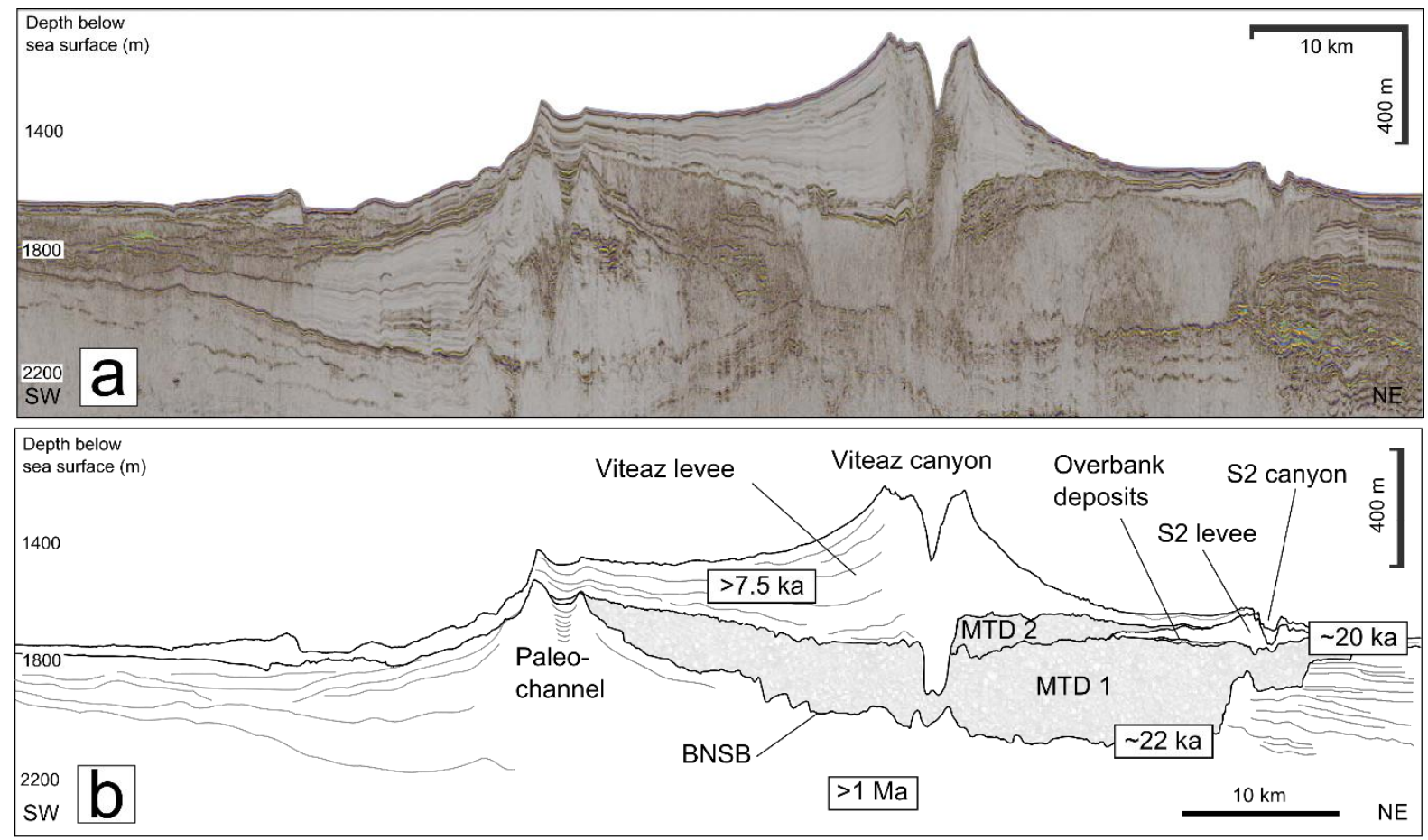

\begin{tabular}{|c|c|}
\hline P7.5 ka & -Viteaz/Danube Levee
\end{tabular}


Figure 3 a) Seismic Line 11. b) Line drawing of the interpreted seismic line (Line 11). BNSB = base Neoeuxinian sequence boundary, MTD = mass transport deposit. For location of the seismic line see Fig. 1. c) Schematic stratigraphic column of the key units in the Danube Fan that are the focus of this study.

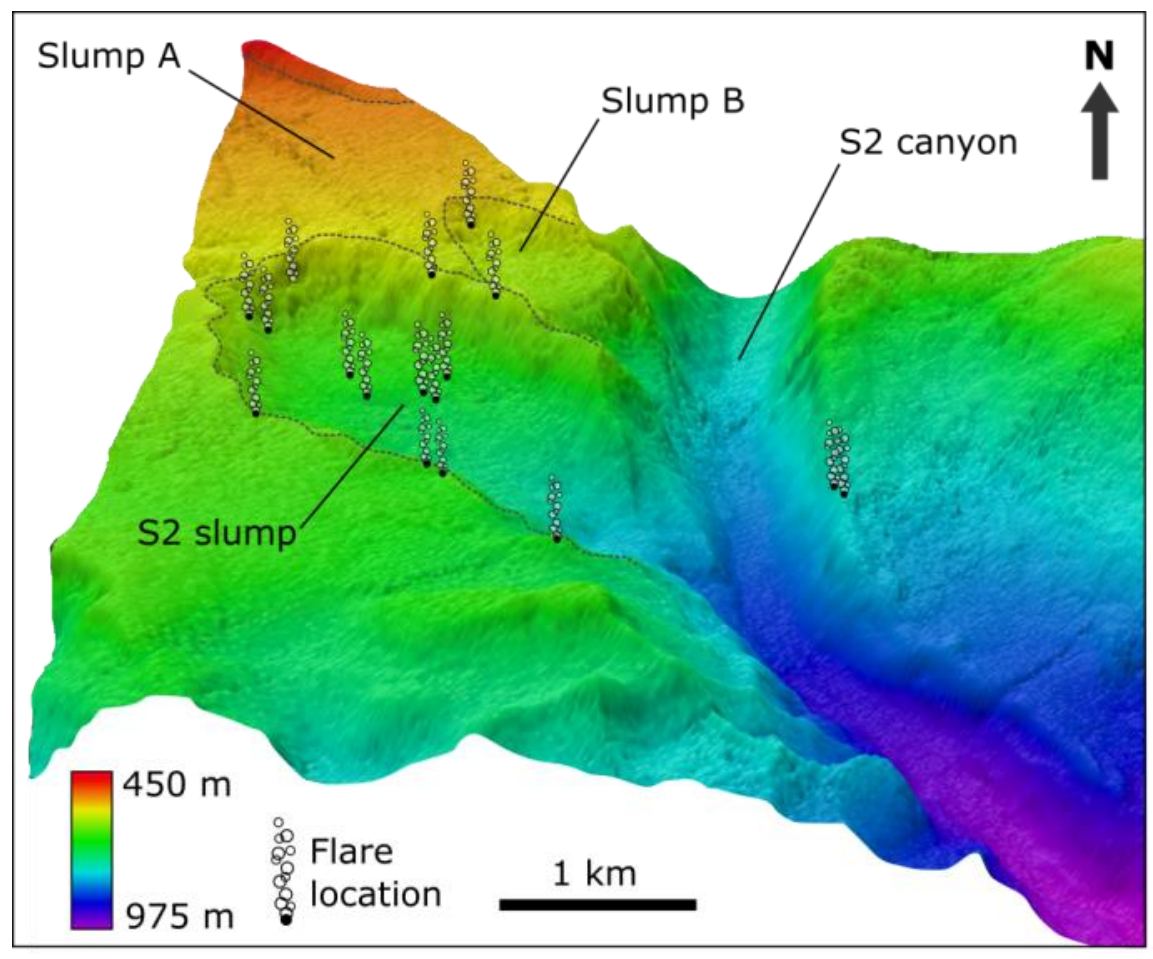

Figure 4 3D perspective view of the S2 canyon and slump to show the location of flares identified during the MSM34 cruise in the area. The dashed lines delineate the edges of the 3 slope failure features - the S2 slump, slump A, and slump B. The majority of slump A is not imaged in the MSM34 bathymetry; however, this can be identified clearly in the bathymetric data acquired during the GHASS cruise (Ker and Riboulot, 2015). For the purposes of the 3D visualization, a 10x vertical exaggeration has been applied.

\section{Gas migration pathways}

The seismic data acquired during cruise MSM34 show several amplitude anomalies that are interpreted as potential gas migration pathways. They are subdivided into migration pathways related to lithology, and gas chimney-like structures.

\section{Migration pathways related to lithology}

In the vicinity of the S2 slump the BSR is closer to the seafloor than in adjacent areas, although the BSR to approach the base of the chaotic, deformed strata (MTD 4) beneath the S2 slump (Fig. 7). Beneath the S2 Canyon, the BSR is clearly defined by the termination of several high amplitude reflections, with patches of enhanced amplitudes along the BSR and in the sediments underlying the S2 slump. Several 
277 S2 slump (Fig. 8), and correlate with the position of observed flares at the seafloor.

278 In the levee sediments to the northeast of the S2 Canyon, there are two high amplitude horizons; at the

279 base of the package of well-laminated near seafloor sediments, and within a unit characterized by

280 relatively seismically transparent facies (Fig. 6). These two horizons are truncated along the canyon wall

281 and correlate with the position of flares observed during the MSM34 cruise. A similar relationship is

282 observed further to the northeast along the canyon.

\section{$\underline{\text { Gas migration structures }}$}

In the seismic data, numerous structures have been identified that are tens-of-meters in diameter, conical in geometry, and are capped by high amplitudes underlain by zones of acoustic blanking (Figs. 7-10). Based on observations in the seismic data these structures can be categorized into Groups A, B and C, based on their dimensions, amplitude characteristics and geometry (Table 3).

Table 3 Characteristics of the 3 groups of vertical migration structures identified in the MSM34 seismic data.

\begin{tabular}{|c|c|c|c|}
\hline & Group A & Group B & Group C \\
\hline Number & 26 & 15 & 7 \\
\hline Geometry & $\begin{array}{l}\text { Narrow (10s to } 100 \text { s of } \\
\text { m), steep sided } \\
\text { structures }\end{array}$ & $\begin{array}{l}\text { Conical, narrow peak } \\
(10 \text { s to } 100 \mathrm{~s} \mathrm{~m}) \text { and } \\
\text { broad base (several } \\
100 \mathrm{~m})\end{array}$ & $\begin{array}{l}\text { Varied, some broad and } \\
\text { elongate, others patchy } \\
\text { and dispersed }\end{array}$ \\
\hline $\begin{array}{l}\text { Amplitude } \\
\text { characteristics }\end{array}$ & $\begin{array}{l}\text { High amplitude at top, } \\
\text { with blanking or dimmed } \\
\text { amplitudes below }\end{array}$ & $\begin{array}{l}\text { High amplitude at the } \\
\text { peak and to the edges, } \\
\text { with blanking or dimmed } \\
\text { amplitudes at the center } \\
\text { of the structure }\end{array}$ & $\begin{array}{l}\text { Broad area of high } \\
\text { amplitudes, or patchy, } \\
\text { dispersed high } \\
\text { amplitudes, less well } \\
\text { defined }\end{array}$ \\
\hline $\begin{array}{l}\text { Active } \\
\text { migration? }\end{array}$ & $\begin{array}{l}\text { Associated with active } \\
\text { flares where they extend } \\
\text { to the seafloor }\end{array}$ & $\begin{array}{l}\text { Associated with active } \\
\text { flares where they extend } \\
\text { to the seafloor }\end{array}$ & $\begin{array}{l}\text { Associated with active } \\
\text { flares where they extend } \\
\text { to the seafloor }\end{array}$ \\
\hline
\end{tabular}

The structures in Group A and B are both characterized by distinct high amplitude anomalies, and/or

291 acoustic blanking, and are differentiated primarily by their geometry and size, with Group B being more

292 complex in structure and larger in size (100s of $m$ in diameter). Group B are also frequently associated 
294 structures (e.g. Fig. 8). Several of the larger features in Group B show stacked concentric circles of high 295 seismic amplitudes, centered on a zone of acoustic blanking (Fig. 9). Both Group A and B are 296 characterized by distinct chimney-like shapes, with circular to elliptical horizontal geometry when 297 observed in the 3D seismic data. Group C are less well defined in the seismic data, and do not exhibit 298 the same 'chimney-like' shape, with some characterized by discrete, broad high-amplitude anomalies, 299 and others as clusters of chaotic seismic facies with patchy high amplitudes (e.g. Fig. 8). 


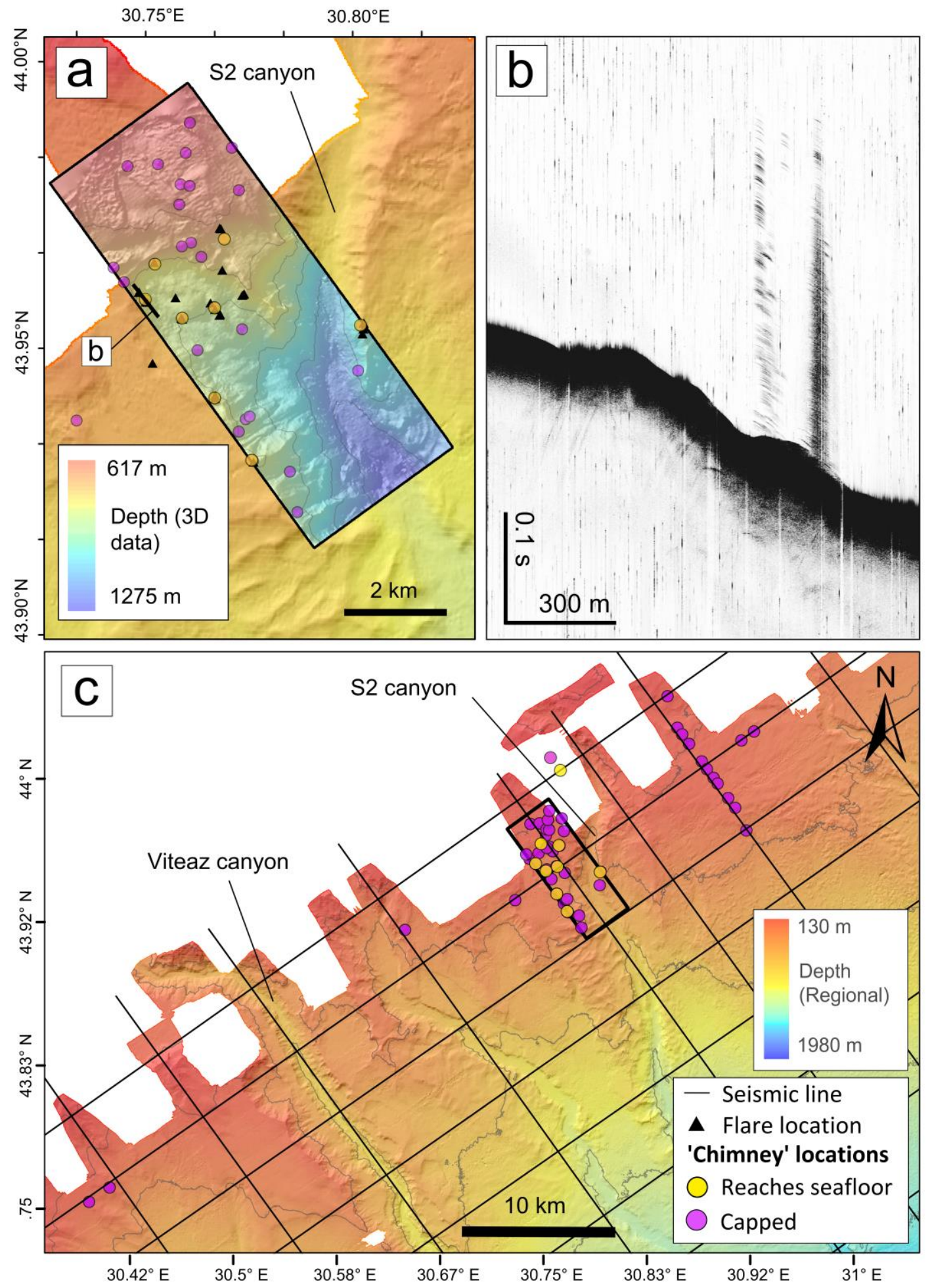

Figure 5 a) Map of gas migration structures identified in seismic data, and flares observed in high frequency sub-bottom profiler data in the vicinity of the $\mathbf{S 2}$ canyon. b) Example of a flare observed in the water column, location of the line is shown in (a). c) Map of gas migration structures identified in seismic data across the MSM34 study area. 

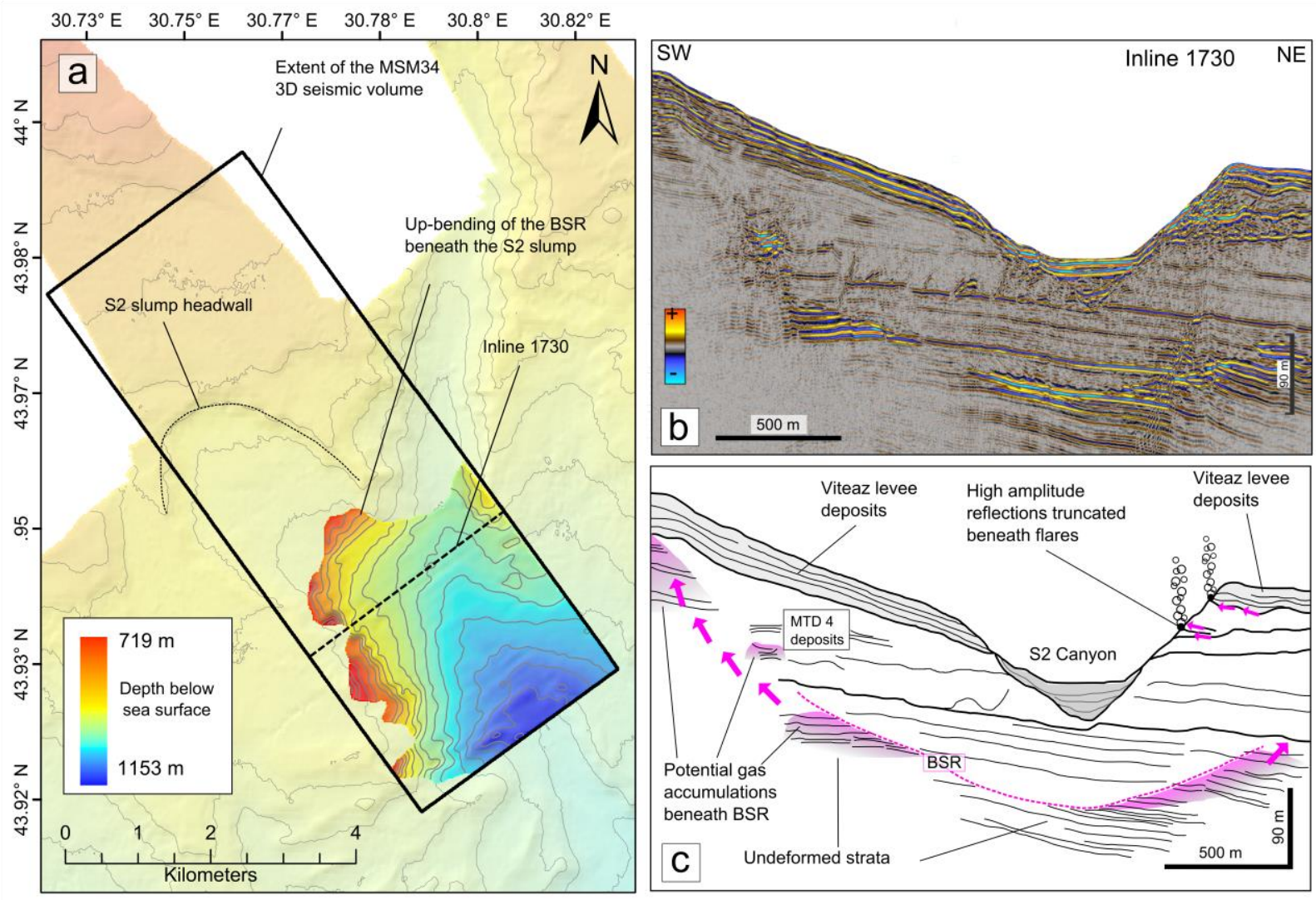

Figure 6 a) Map to show the extent of the BSR in the 3D seismic data. The S2 slump headwall is outlined on the seafloor bathymetry for reference. b) Inline 1730: seismic profile. c) Inline 1730: Line drawing. The BSR bends upward beneath the S2 slump. Increased amplitudes terminating and stacking along the potential pathway of the BSR image vertical gas migration leading to potential gas accumulations near the seafloor along the southwestern sidewall of the S2 slump. Along its eastern flank the S2 Canyon truncates two highamplitude horizons in the levee deposits that correlate to the position of flares along the canyon. 

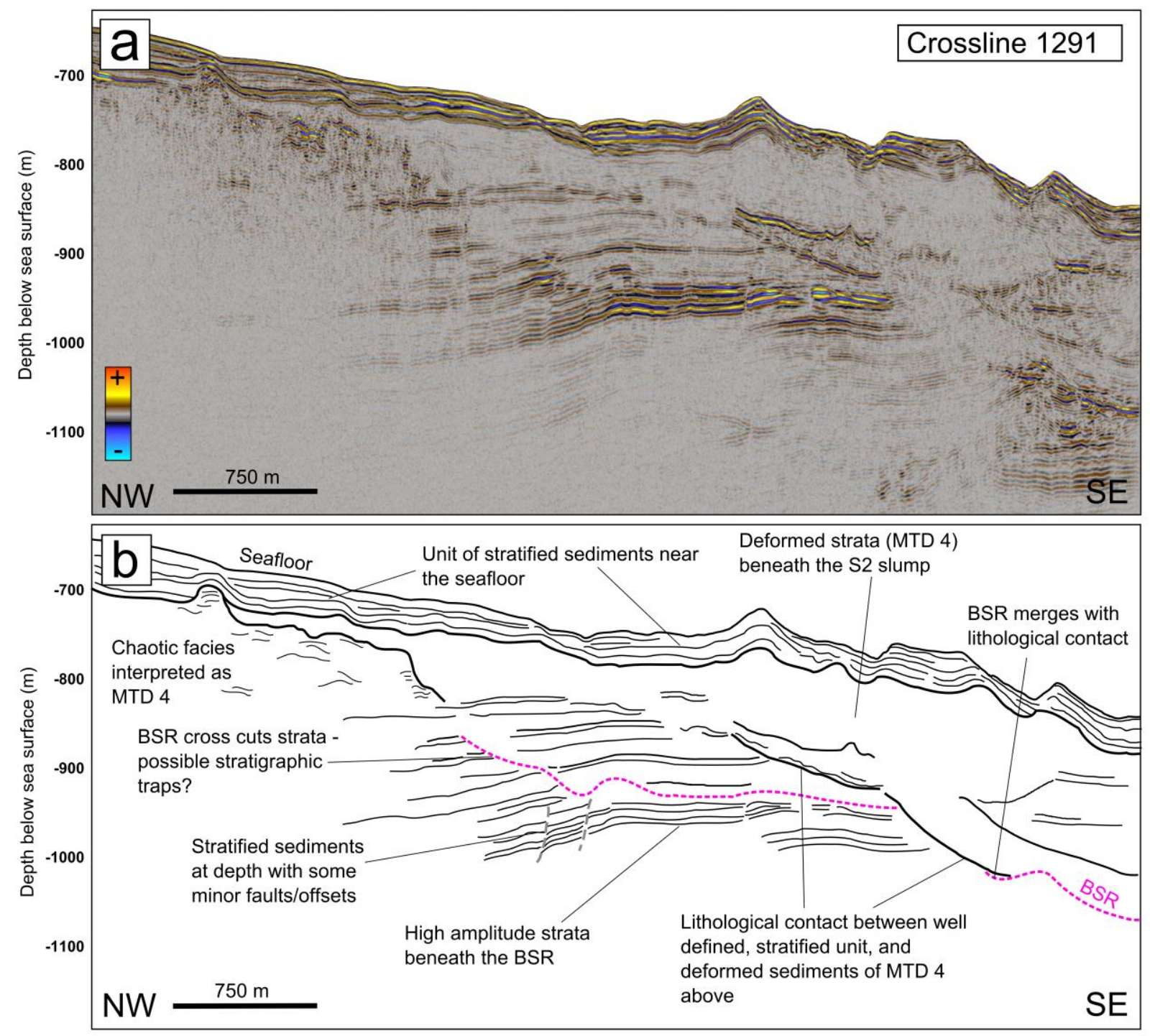

Figure 7 a) Crossline 1291: seismic line showing the position of the BSR relative the lithological contact beneath the MTD. The position of the BSR is reinforced through observations of Inline 1730 (Fig. 6). See Fig. 2 for line location. b) Crossline 1291: interpreted line drawing. The position of the BSR merges with the lithological contact to the SE. To the NW the BSR is clearly distinguished by the termination of high amplitudes. The stratified sediments beneath the BSR are offset by minor faults, with possible small stratigraphic traps along the BSR. 


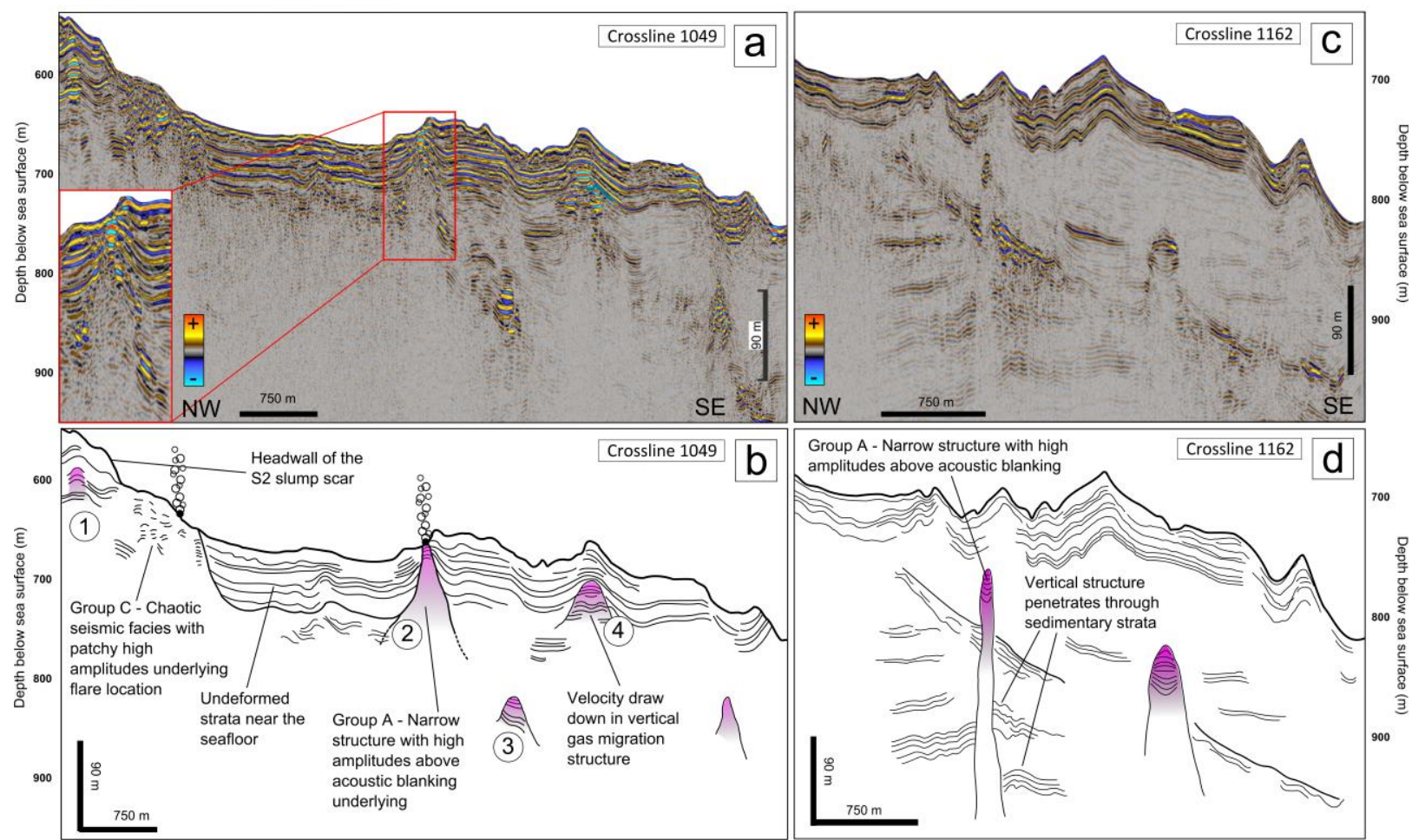

Figure 8 a) Crossline 1049: seismic line showing examples of Group A and C gas migration features. Inset enlarged view of narrow, conical structure showing high amplitude reflections capping a column of acoustic blanking. See Fig. 2 for line location. b) Crossline 1049: interpreted line drawing. Structures 1, 3 and 4 are capped by overlying sediments and do not reach the seafloor. Structure 2 reaches the seafloor and underlies the location of an identified flare. There is also a flare above the chaotic seismic facies interpreted as MTD deposits associated with the S2 slump. c) Crossline 1162: seismic line showing an example of Group A gas migration features. See Fig. 2 for line location. d) Crossline 1162: interpreted line drawing. These narrow, vertical structures clearly cross-cut the sedimentary strata at depth. 


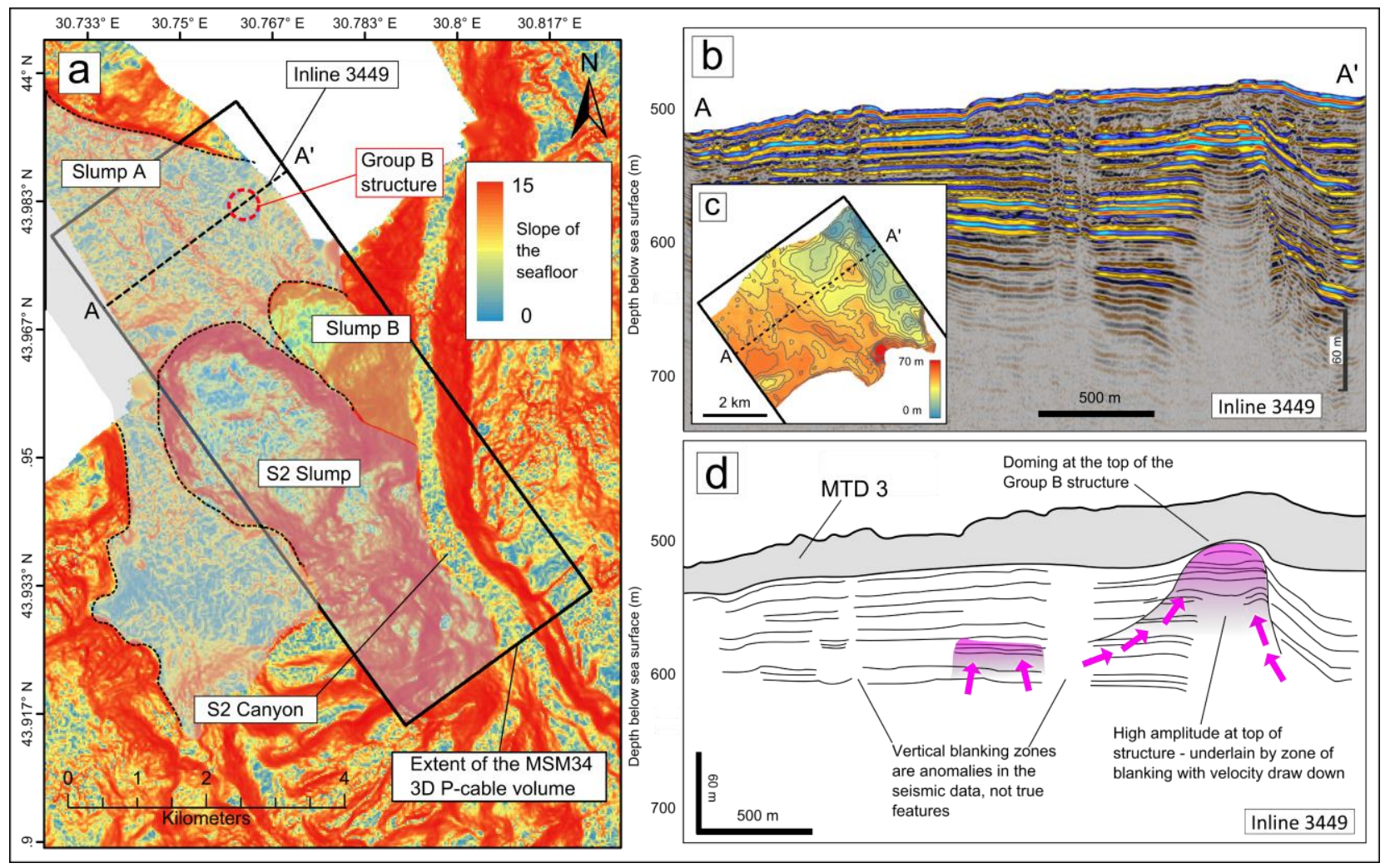

Figure 9 a) Slope map of the seafloor - the three slump features near the S2 canyon are outlined. Slump A is associated with MTD 3, shown in (b) and (d) that caps the chimney. b) Line 3449: seismic line showing an example of a Group B gas migration structure. c) Isopach map of the MTD 3 unit. The thickness of the unit decreases above the large gas-migration feature and dome structure (c) in the NE of the study area. The heavy black line indicates the extent of the 3D seismic volume. d) Line 3449: interpreted line drawing. The Group B structure here does not reach the seafloor; it is capped by MTD 3 associated with the slope failure (Slump A) upslope of the S2 slump. There appears to be doming at the top of the structure, resulting in thinning of the overlying sediments.

\section{Discussion}

\section{Sequence stratigraphy}

Our interpretation of the regional seismic stratigraphy differs from previous work such as Popescu et al.

303 (2001), who interpret the BNSB as a shallower horizon underlying a smaller MTD 2 (see Fig. 3). The major

change between the older interpretations of the position of the BNSB and ours presented in this paper,

is that Popescu et al. (2001) placed the sequence boundary above the S2 levee (Popescu et al 2001,

their Fig. 3), and we are placing it well below the S2 levee. However; there is general consensus that the example Popescu et al. 2001 Fig. 4; Constantinescu et al. 2015 Fig. 3). The new seismic data allows the 
established without ambiguity, and the MTD seen in the Popescu et al. (2001) and Constantinescu et al.

311 (2015) figures is well below the S2 levee confirming that the S2 levee is within the Late Pleistocene fan.

312 Since the S2 levee is below the main levee of the Late Pleistocene fan, it represents a channel system that was active briefly after MTD 1 was deposited ( $22 \mathrm{ka})$, and before the main channel was occupied.

As our sedimentation rate estimates are based on widely spaced regional 2D seismic lines, there is some uncertainty in the calculations (Table 3); however, the calculated values provide an indication of the relative sedimentation rates in the region. Due to the difference in our sequence stratigraphic interpretations to those of previous studies, these values are significantly higher than those of Winguth et al. (2000).

\section{Nature of the observed seismic anomalies}

320 We interpret the high amplitude horizons (Fig. 6) as gas-charged sediments that are supplying gas to the flares where they are truncated by the S2 Canyon. In several locations, particularly within the large levee deposits of the Viteaz Canyon, there are discrete patches of high seismic amplitudes along some strata. This could be the result of lateral migration of gas along these strata, forming shallow accumulations of gas within the levee sediments. The vertical, sub circular to elliptical disruptive features, on the other hand, are most likely associated with gas migration, with Group A and B comprising more classical chimney structures, and Group C as anomalous features associated with gas migration and/or accumulation. While these structures may not exhibit all the characteristics of 'true' seismic chimneys, they are certainly indicative of upward gas migration through sediments that has resulted in the formation of vertical features characterized by regions of acoustic blanking and capped by high amplitudes that may be interpreted as gas accumulations. 48 such structures are observed in the MSM34 seismic data, with the majority clustered in the vicinity of the S2 Canyon; however, there is an inherent data bias here due to the location of the 3D seismic volume. Those that do reach the seafloor correlate to the position of flares observed during the cruise, indicating that there is active upward migration of gas occurring. However, there are also vertical gas migration structures that accumulate 
gas at their summit, being 'capped' by the overlying sediments and do not extend to the seafloor (Figs. 5 and 8).

These gas migration structures appear to be restricted to water depths of $<700 \mathrm{~m}$, with none identified in the seismic data in the more distal reaches of the Danube Fan. Some of the structures in Group B that do not reach the seafloor (i.e. those that are capped by overlying sediment), show evidence of doming above the chimneys, with reduced thickness in the overlying sediment package (Fig. 9). The structure in Fig. 9 seems to appear in connection with a local summit of the base MTD C horizon. Based on the interpretation of these horizons across the extent of the 3D seismic volume, this local summit is likely an effect of doming caused by gas, which results in upward bending of the strata. Horizontal layering of the neighbouring sediments would not be expected in case of tectonically forced folding.

\section{Formation and role of gas chimneys in qas migration}

There are several factors that may control the upward propagation of gas and the formation of these chimney-like structures; the rate of gas supply, contrasting lithology forming seals and localized variations in lithological properties such as porosity and permeability. Here we discuss the factors that likely influenced the formation of the three groups of structures identified in the MSM34 seismic data.

\section{Group A structures}

The structures in Group A are characterized as narrow, steep sided gas migration features, with an overall simple geometry, somewhat similar to those observed offshore Norway (Karstens and Berndt, 2015), Namibia (Moss and Cartwright, 2010), northern Australia (Rollet et al., 2009), and in the Congo

354 Basin (Gay et al., 2006; Ho et al., 2012). Several such structures are observed beneath the S2 slump, 355 where they appear to correlate with locations where the overlying unit of stratified sediments thins out (Fig. 8), suggesting that upward gas migration exploits the thinned, weakened overburden at such points. The high seismic amplitudes observed at the peak of these structures are indicative of shallow gas accumulations (Rollet et al., 2009). However, as some of these chimney-like structures are capped 

chimney-like structures do reach the seafloor, they correlate to the observed flares. The absence of any resolvable erosional features, or pockmarks, at the seafloor above these features again suggests that the venting is gradual and focused (Moss and Cartwright, 2010), compared to the intermittent more explosive, blow-out type venting observed in locations such as offshore Nigeria (Løseth et al., 2011). Pockmarks are, however, observed upslope of the study area in water depths of $\sim 500 \mathrm{~m}$, and further to the northwest along the shelf edge (Riboulot et al., 2017).

\section{Group B structures}

The structures in Group B are generally larger in size, typically with a more complex internal geometry than those of Group A. In particular, the near-circular, capped gas migration structures upslope of the S2 slump (Fig. 9) have a geometry that is reminiscent of a larger ( $\mathrm{km}$-scale) feature observed in 2D seismic data on the Hikurangi Margin, offshore New Zealand. There, high amplitudes that correlate with high seismic velocities ( $2150 \mathrm{~m} / \mathrm{s}$ ) are observed on the edges of a chimney-like feature, with blanking and low velocities $(\sim 1850 \mathrm{~m} / \mathrm{s})$ at the center and below ( $1600 \mathrm{~m} / \mathrm{s})$ (Fraser et al., 2016). This is interpreted as gas hydrates forming at the boundary of the chimney structure (corresponding to high seismic amplitudes and velocities), with free gas at the center (corresponding to seismic blanking and low velocities). A similar interpretation could be possible here; however, given that these structures lie above the predicted GHSZ, it is more likely that the high seismic amplitudes correspond to free gas accumulations at the edges of the structures, rather than hydrate. The presence of free gas in sediments can be characterized in seismic data by both high and low amplitudes (Ecker et al., 2000; Hornbach et al., 2003), and it may be that the variation across these chimney structures is due to a change in the concentration of free gas in the sediments, or the degree of disruption in the sediments caused by the upward flow of free gas (Cathles et al., 2010; Karstens and Berndt, 2015). is also evidence of seafloor doming above some of the capped chimney structures, along with possible deformation of the sediments (Fig. 9). Flattening the seismic volume along a horizon that caps this 
chimney structure (i.e. the base of MTD 3) reveals decreased sedimentation above the domed chimney, which is consistent with previous work by Koch et al. (2015) on similar structures in the very shallow subsurface offshore New Zealand. The fact that the domed structures are preserved in the subsurface indicates that the dome morphology can sustain burial, as suggested by Koch et al. (2015). This would suggest that the MTD unit capping the gas migration structure was deposited following the development of the gas chimneys in this region. Based on the stratigraphic relationships, Slump A (Fig. 4) pre-dates the $S 2$ slump, and therefore this unit must have been deposited prior to 20 ka, providing a minimum age constraint for the development of the gas chimneys. However; precise timing of the development of individual chimneys is not possible. Gas doming has been observed elsewhere in the Black Sea on the Turkish continental slope (Golmshtok et al., 1992). In that location, the dome reaches the seafloor and correlates with the location of a gas vent at the seafloor. The absence of a high amplitude 'cap' at the apex of the capped chimneys may be related to the deposition of MTD 3 (Fig. 9), as the deposition of this unit may have eroded the top of the original chimney structure (which may have been connected to the seafloor), resulting in a sealed vertical migration pathway. Potentially as a result of limited gas supply, the original high amplitude 'cap' has not been replenished since this occurred. The possible deformation of sediments in the vicinity of these larger chimney structures (e.g. Fig. 9), suggests that this deformation, or minor folding, of the sediments may have resulted in gas being channeled towards a particular location, allowing the buildup of an accumulation sufficient to generate hydrofracturing and form a large chimney.

\section{Group C structures}

While the structures in Groups A and B can be interpreted as true gas migration structures, with many of the typical features of chimneys, those in Group $\mathrm{C}$ are more anomalous and do not follow the same characteristics. Some of the structures in Group C are likely the result of small, shallow gas accumulations, similar to those described by Andreassen et al. (2007) in the Barents Sea, the locations of which are controlled by minor structural traps in the channel-levee complexes of the Danube Fan.. 
distributions of high amplitudes in the seismic data (e.g. Figs. 6 and 8). These are likely due to the

413 dispersed accumulation of gas within the sediments, which may be controlled by localized, small-scale

414 heterogeneity in the lithology (Deckers, 2015; Thöle et al., 2016). This is particularly evident at the foot of the S2 slump headwall, where the MTD is exposed at the seafloor, and corresponds with the location of several flares (Figs. 4 and 10).

\section{Evidence of gas beneath the BGHSZ and hydrofracturing}

418 Beneath the BSR gas saturation generally increases with proximity towards the BSR (Berndt et al., 2004).

419 In the vicinity of the S2 Canyon, high amplitude reflections abruptly terminate at the BSR, indicating that

420 gas migration/accumulation is focused along certain stratigraphic intervals, as was also observed in

421 other hydrate provinces (e.g. Vanneste et al., 2001). Beneath the S2 channel, the BSR appears to act as

422 a seal, preventing upward gas migration beneath the canyon. However, to the west, underlying the S2

423 slump, the BSR is warped upward. Increased amplitudes terminate along the BSR appear at irregular

424 intervals and with variable strength (Fig. $6 \&$ 7). The upward continuation of the BSR leads to patches of

425 high amplitudes near the seafloor, some of which correlate to flares in the water column. Vertical

426 correlated stacks of high amplitudes next to the seafloor in correlation with active gas expulsion at the

427 seafloor suggests that gas may be migrating along the BGHS as it bends upward beneath the slump

428 deposits, and that gas is then 'leaking' from beneath the BSR and may be forming accumulations of free

429 gas near the seafloor and forming small gas chimneys that feed the observed flares. This is further

430 evidenced by the observation of several flares along the northern edge of the S2 Canyon (Fig. 6). These

431 flares correlate with the truncation of high amplitude reflections and minor disturbances in the

432 sediments along the edge of the canyon (Figs. 6 and 10), indicating that free gas may be migrating along

433 these horizons, forming flares where they are exposed at the seafloor. Levee deposits consist of fine

434 grained muds, with intermittent beds of silty and sandy sediments, as observed in cores recovered from

435 this region (Constantinescu et al., 2015; Lericolais et al., 2013). We therefore interpret these high

436 amplitude reflections as coarser grained sediments with higher porosity and permeability which 
facilitate the migration of free gas through the levee towards the canyon whereas fine-grained, muddy

438 units hinder vertical gas migration.

439

440

442

443

\section{Mass transport deposits and gas migration}

It should be noted that within a chaotic body such as an MTD there are other possible explanations for high amplitude patches in the seismic data, such as variations in lithology. Without additional data from core samples, it is not possible to rule this out in this location. It is not immediately apparent as to why some structures are capped, and others extend to the seafloor. Based on the observation of the position of the BSR corresponding with the base of MTD 4 deposits beneath the S2 slump scar in the seismic data, it would appear that the sediments of MTD 4 also facilitate the migration of gas, with discontinuities in the chaotic seismic facies likely providing flow conduits that result in the formation of gas migration features and flares (Thöle et al., 2016). Upward migration of gas through the sediments is also prevented by MTD deposits in some cases (Sun et al., 2017). This would explain the capped structures that are observed upslope of the S2 slump (Figs. 4 and 9). The chimneys terminate at the contact with the MTD 3 associated with Slump A, which indicates that the sediments of the MTD form a seal, preventing upward gas migration. while minor variations in porosity and/or permeability of sediments may already be sufficient to allow or control the movement of gas. This is of particular significance in the case of MTD sediments as these are highly heterogeneous and have limited lateral connectivity (Manley et al., 1997; Moscardelli et al., 2006; Piper et al., 1997). The high concentration of vertical gas migration features within MTD 4 supports this, indicating that the positions at which these structures are able to propagate upwards through the MTD sediments may correlate to sediments with slightly higher porosity/permeability.

MTD deposits on continental slopes generally involve a mixture of lithologies from the original failed area and transported by various gravitational processes (Mulder and Cochonat, 1996). Short transport distances would prevent effective sorting and consequently result in low permeability of the MTD, forming a seal unit, unless the failed deposits were already well sorted. As the primary source of failed material in the Danube Fan is likely to be levee sediments presenting a mixture of fine-grained and 
slightly coarser spill-over deposits. The thickness of deposits from failure of such material most likely corresponds to sealing effectiveness as shown by the correlation between the thickness of the MTD 4 and the location of flares, which generally occur where the MTD thins to $<25 \mathrm{~m}$. On the other hand, active gas migration structures capped by an MTD unit should lead to gas accumulation at the base of the MTD, or to gas migration along its base. We do observe increased amplitudes at the top of some of these capped structures (Fig. 8), but this could also be the effect of the impedance contrast between the MTD und underlying deposits. It is also possible that gas flow rates have been low since the MTDs were emplaced, resulting in limited accumulation and lateral migration of gas underlying those MTD units that act as seals.

\section{Hydrofracturing}

Geochemical analysis of porewater samples during the MSM34 cruise indicates that a dry gas system is present in the Danube Fan, with little to no gas dissolved in porewater (Bialas et al. 2014, Haeckel, pers. comm. 2016). Amplitude anomalies within the gas chimneys observed in the MSM34 seismic data occur preferentially along the continuation of high amplitude horizons (Fig. 9) (Chenrai and Huuse, 2017; Koch et al., 2015). This could be due to gas gradually accumulating over a period of time at one stratigraphic horizon, until a sufficient volume builds up to exceed the overburden pressure, at this point hydrofracturing occurs, and the gas migrates upward. This would lead to the development of a series of stacked gas accumulations in the sediment column, forming a chimney-like structure, as observed in the seismic data (Fig. 9). In order for hydrofracturing to occur, the pressure must exceed the combined least principle stress and tensile strength of the sediment (Karstens and Berndt, 2015; Maestrelli et al., 2017). The buoyancy of free gas exerts a localized pressure on the seal unit, which is directly proportional to the column height of the gas accumulation (Cathles et al., 2010). The height of the gas column required to breach the overburden seal can be calculated using the following equation (Karstens and Berndt, 2015):

$P_{w m}=P_{w n}\left(\gamma_{w c} / \gamma_{w n}\right)$ 
where $P_{w m}$ is the capillary pressure between methane and water, $P_{w n}$ is the capillary pressure between nitrogen and water ( $3 \mathrm{MPa}), \gamma_{\mathrm{wc}}$ is the interfacial tension coefficient for methane and water at $7.5 \mathrm{MPa}$ and $13.94^{\circ} \mathrm{C}\left(65 \times 10-3 \mathrm{~N} / \mathrm{m}\right.$; Khosharay and Varaminian, 2013), and $\gamma_{w n}$ is the interfacial tension coefficient for nitrogen and water $\left(72.8 \times 10^{-3} \mathrm{~N} / \mathrm{m}\right)$ (Karstens and Berndt, 2015). As an estimate for the locations of gas accumulation we average the imaged depth to the base of the chimneys imaged in our seismic data, therefore $\mathrm{P}_{\mathrm{wm}}$ can be calculated as $2.679 \mathrm{MPa}$, assuming only vertical gas migration. It should be noted that a continuous gas column is one possible end-member of the potential saturation spectrum. This value for $\mathrm{P}_{\mathrm{wm}}$ can therefore be used to determine the gas column height required to breach the overburden seal, using the following equation (Karstens and Berndt, 2015; Zander et al., 2017b):

$H_{h f}=P_{w m}\left(g \times\left(\rho_{w}-\rho_{C H_{4}}\right)\right)$

where $H_{h f}$ is the gas column height required for hydrofracturing to occur, $g$ is the gravitational acceleration $\left(9.81 \mathrm{~m} / \mathrm{s}^{2}\right), \rho_{\mathrm{w}}$ is the density of formation water $\left(1025 \mathrm{~kg} / \mathrm{m}^{3}\right)$ (Karstens and Berndt, 2015; Zander et al., 2017b), and $\rho_{\mathrm{CH} 4}$ is the density of methane $\left(58.54 \mathrm{~kg} / \mathrm{m}^{3}\right.$ ) (calculated for values of $7.5 \mathrm{MPa}$ and $13.94^{\circ} \mathrm{C}$ using the SUGAR Toolbox; Kossel et al., 2013). Based on this calculation, the gas column height required for hydrofracturing would be $283 \mathrm{~m}$. The average depth to the base of the chimney structures in our seismic data is 158.3 mbsf, indicating that gas column height alone would be insufficient to result in hydrofracturing and seal breaching. However, due to the limited depth of penetration in our seismic data, we are not able to definitively image the base of the chimneys, and as such, there is a significant margin of error in the calculation.

Due to the limited depth of penetration in the seismic data the source of the gas that is feeding into these structures is unclear. However, in the vicinity of the S2 slump the position of the BSR correlates with a lithological contact between an MTD 3nd underlying layered sediments. This suggests that the boundary between the two units may be acting as a migration pathway for gas along the base of gas hydrate stability (BGHS) (Fig. 7). This is consistent with the observation of flares overlying chaotic seismic 
514 the seafloor and provide a gas conduit to feed the flares (Fig. 8 and 10). Unfortunately, in our seismic

515 data we are unable to image the base of these structures. Geochemical data suggest that the gas is

516 biogenic in origin (Bialas et al., 2014). Although deeper thermogenic reservoirs may be present in the

517 area (Olaru-Florea et al., 2014; Starostenko et al., 2010), there is no evidence to suggest that these are

518 connected to the near-surface gas system.
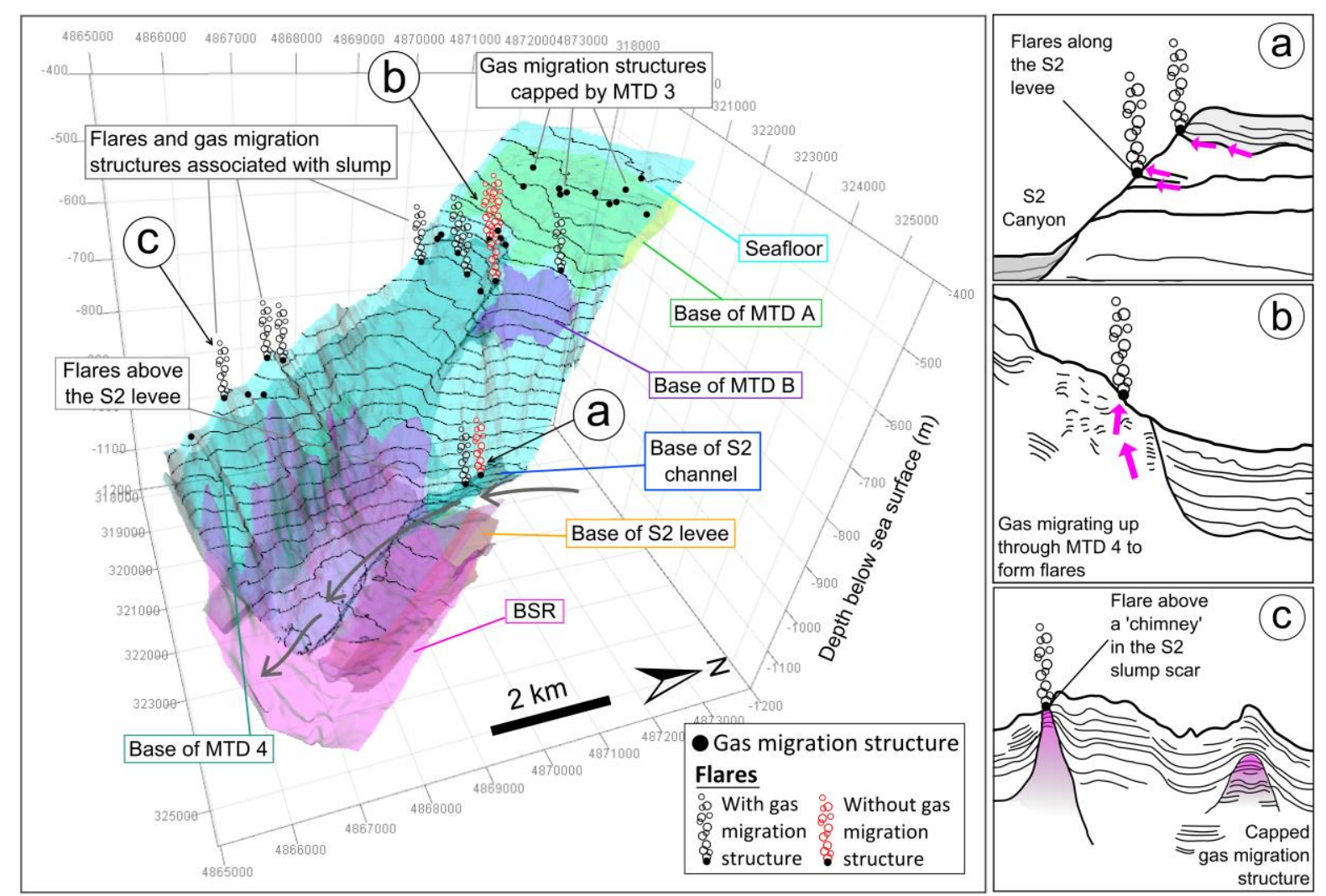

Figure $103 D$ view of the BSR, flares and gas migration structures in relation to key stratigraphic units across the extent of the $3 D$ seismic volume. a) Gas charged horizons truncated by the S2 canyon forming flares. b) Chaotic MTD unit allowing upward migration of gas to form flares in the S2 slump. c) Gas migration structure extending upwards to the seafloor along the western edge of the S2 slump, and a capped gas migration structure. In this area gas clearly migrates up from beneath the upbending BSR (see Fig. 4).

\section{Gas migration and submarine slope failure?}

520 There are several ways in which gas hydrates may influence slope stability and potentially contribute to

521 the formation of submarine landslides; overpressure beneath low-permeability, hydrate-bearing

522 sediments resulting in hydrofracturing, dissociation of hydrates resulting in excess pore pressure, and

523 plastic deformation of hydrate-bearing sediments causing glacier-style deformation of sediments 
524 (Crutchley et al., 2010; Mountjoy et al., 2014; Phrampus and Hornbach, 2012). There is no evidence of

525 the latter style of deformation in this area so this will not be discussed further. Studies in other regions

526 (Li et al., 2016; Mountjoy et al., 2014), have proposed that hydrates may play a role in triggering slope

527 failure due to the build-up of overpressure in high porosity sediments beneath low-permeability,

528 hydrate-bearing sediments in the GHSZ. The removal of large volumes of sediment during such an event

529 could then further destabilise hydrates due to a change in the thermal regime of the near seafloor

530 sediments. However, in the upper section of the sediment column the pressure would likely be

531 hydrostatic and therefore removal of near-seafloor sediments would not necessarily impact hydrate

532 stability in terms of pressure.

533 In the vicinity of the S2 canyon there are three large submarine slope failures (Slump A, B and the S2

534 slump (Fig. 4; Table 2), Slump A is the oldest, and the S2 slump the most recent. The average height of

535 the headwall scarp at the S2 slump is $\sim 25 \mathrm{~m}$, resulting in an estimated volume of $0.36 \mathrm{~km}^{3}$ of sediment

536 being removed in this slope failure event (Badhani, 2016). However, there is no evidence for deposits

537 downslope or in the canyon that could be related to this event suggesting that the S2 Canyon was active

538 at the time of the slope failure.

539 Previous work in the Monterey (Locat and Lee, 2002) and Cook Strait (Mountjoy et al., 2009) canyons

540 indicates that undercutting at the toe of a slope due to the erosive action of hyperpycnal turbidity

541 currents in canyons may result in axial incision of the canyon floor, triggering slope failure due to

542 oversteepening. In case of the S2, oversteepening due to the canyon undercutting likely played a role

543 as well but overpressure generation due to rapid deposition of slope sediments may have also

544 contributed to slope instability.

545 Based on the relative timing of the slope failures surrounding the S2 Canyon, and the observed seafloor

546 doming beneath MTD 3, we can determine that at least some of the gas migration structures have been

547 active since prior to the slope failures occurred. The deposition of the MTD units then capped many of

548 the gas migration structures; however, some have been able to breach this unit and extend to the 
seafloor to form active gas flares (Fig. 10). Whether the structures reach the seafloor or not appears to

550 be primarily controlled by the thickness and lithology of the overlying sediment, with thinner, chaotic

551 MTD units being readily breached along the slope failure scarp of the S2 slump, resulting in a

552 concentration of flares in this area.

\section{Conclusions}

554 Gas migration structures are abundant in the vicinity of the S2 Canyon and the surrounding sediments

555 of the Danube Fan, occurring at water depths of $<700 \mathrm{~m}$. Where these chimneys reach the seafloor,

556 they correspond to observed gas flares in the water column. We classified the structures into three

557 groups based on their seismic characteristics, size, and geometry. Groups A and B are more reminiscent

558 of true gas chimneys at varying scales and complexities, whereas Group C contains anomalous gas

559 accumulations and features related to MTDs. The location of these structures appears to be controlled

560 by: a) overlying units acting as seals, b) variations in lithology across heterogeneous sediments

561 (particularly MTDs), and c) intermittent/gradual gas supply leading to the development of stacked

562 accumulations of gas. The MTD units identified in the 3D seismic volume appear to have contrasting

563 lithological properties; MTD 3 is thicker and acts as a seal, preventing upward gas migration from several

564 structures, whereas MTD 4 is more irregular in thickness, and seems to facilitate the migration of gas

565 through the chaotic seismic facies, resulting in the formation of numerous flares. A clear determination

566 of the source of the gas is not possible, but geochemical data indicate that it is biogenic in origin.

567 Slump events probably resulting from erosive undercutting, but gas migration may have played a role

568 in the initiation of the slope failures Abundant evidence for gas migration in the area suggests a

569 connection between the slumps and gas migration, although it is not clear whether gas migration

570 facilitates slope failure through overpressure and pre-conditioning of the sediments, or vice versa.

571 However, the capped structures indicate that in others there may be insufficient gas supply to exceed

572 the overburden pressure of the sediments. The younger, chaotic sediments of MTD 4 facilitate the

573 upward migration of gas, particularly around the headwall where the MTD is thinnest, resulting in the concentration of gas flares in this area. 


\section{Acknowledgements}

576 This research was funded by ExxonMobil Upstream Research Company. The research cruise MSM34

577 received funding from the European Union Seventh Framework Programme (FP7/2007- 2013) under

578 the MIDAS project, grant agreement No. 603418, from the German Ministry of Education and Research

579 (BMBF) and the Federal Ministry of Economy and Energy (BMWi) through the SUGAR project (Grant

580 Nos. 03G0819A, 03SX320A, 03G0856A). The regional multi-channel seismic data was kindly provided by

581 the Institute of Marine Science and Technology (IMST-Seislab) of the Dokuz-Eylül University, Izmir,

582 Turkey. We would like to thank the captains and crew of RV MARIA S. MERIAN cruise MSM34 as well as

583 the GEOMAR lab technicians for their excellent support. We especially thank Dirk Klaeschen, Anke

584 Dannowski and Cord Papenberg for their help with seismic and OBS data processing.

585

586

587

588

589

590

591

592

593

594

595

596

597

598

599

600

601

602

603

604

605

606

607

608

\section{References}

Andreassen, K., Nilssen, E.G., Ødegaard, C.M., 2007. Analysis of shallow gas and fluid migration within the Plio-Pleistocene sedimentary succession of the SW Barents Sea continental margin using 3D seismic data. Geo-Marine Lett. 27, 155-171. https://doi.org/10.1007/s00367-007-0071-5

Badhani, S., 2016. Slope failures and gas hydrate distribution in the Danube deep-sea fan, NW Black Sea. MSc. Thesis. Christian Albrechts University of Kiel.

Bello, A., Heggland, R., Peacock, D.C.P., 2017. Pressure significance of gas chimneys. Mar. Pet. Geol. 86, 402-407. https://doi.org/10.1016/j.marpetgeo.2017.06.005

Berndt, C., Bünz, S., Clayton, T., Mienert, J., Saunders, M., 2004. Seismic character of bottom simulating reflectors: examples from the mid-Norwegian margin. Mar. Pet. Geol. 21, 723-733. https://doi.org/10.1016/j.marpetgeo.2004.02.003

Bialas, J., Klaucke, I., Haeckel, M., 2014. MSM-34 / 1 \& 2 SUGAR Site Cruise Report. Kiel, Germany.

Bohrmann, G., Ivanov, M., Foucher, J.-P., Spiess, V., Bialas, J., Greinert, J., Weinrebe, W., Abegg, F., Aloisi, G., Artemov, Y., Blinova, V., Drews, M., Heidersdorf, F., Krabbenhoeft, A., Klaucke, I., Krastel, S., Leder, T., Polikarpov, I., Saburova, M., Schmale, O., Seifert, R., Volkonskaya, A., Zillmer, M., 2003. Mud volcanoes and gas hydrates in the Black Sea: new data from Dvurechenskii and Odessa mud volcanoes. Geo-Marine Lett. 23, 239-249. https://doi.org/10.1007/s00367-003-0157-7

Bünz, S., Mienert, J., 2004. Acoustic imaging of gas hydrate and free gas at the Storegga Slide. J. Geophys. Res. Solid Earth 109, 1-15. https://doi.org/10.1029/2003JB002863

Cartwright, J., 2007. The impact of 3D seismic data on the understanding of compaction, fluid flow and diagenesis in sedimentary basins. J. Geol. Soc. London. 164, 881-893. https://doi.org/10.1144/0016-76492006-143

Cartwright, J., Huuse, M., Aplin, A., 2007. Seal bypass systems. Am. Assoc. Pet. Geol. Bull. 91, 11411166. https://doi.org/10.1306/04090705181 
Cathles, L.M., Su, Z., Chen, D., 2010. The physics of gas chimney and pockmark formation, with implications for assessment of seafloor hazards and gas sequestration. Mar. Pet. Geol. 27, 82-91. https://doi.org/10.1016/j.marpetgeo.2009.09.010

Chenrai, P., Huuse, M., 2017. Pockmark formation by porewater expulsion during rapid progradation in the offshore Taranaki Basin, New Zealand. Mar. Pet. Geol. 82, 399-413. https://doi.org/10.1016/j.marpetgeo.2017.02.017

Chepalyga, A.L., 1984. Inland sea basins, in: Velichko, A.A., Wright, H.E., Barnowsky, C.W. (Eds.), Late Quaternary Environments of the Soviet Union. University of Minnesota Press, Minneapolis, pp. 229-247.

Constantinescu, A.M., Toucanne, S., Dennielou, B., Jorry, S.J., Mulder, T., Lericolais, G., 2015. Evolution of the danube deep-sea fan since the last glacial maximum: New insights into Black Sea water-level fluctuations. Mar. Geol. 367, 50-68. https://doi.org/10.1016/j.margeo.2015.05.007

Crutchley, G.J., Geiger, S., Pecher, I.A., Gorman, A.R., Zhu, H., Henrys, S.A., 2010. The potential influence of shallow gas and gas hydrates on sea floor erosion of Rock Garden, an uplifted ridge offshore of New Zealand. Geo-Marine Lett. 30, 283-303. https://doi.org/10.1007/s00367-010-0186-y

Crutchley, G.J., Gorman, A.R., Fohrmann, M., 2007. Investigation of the role of gas hydrates in continental slope stability west of Fiordland, New Zealand. New Zeal. J. Geol. Geophys. 50, 357364. https://doi.org/10.1080/00288300709509842

Deckers, J., 2015. Middle Miocene Mass Transport Deposits in the southern part of the Roer Valley Graben. Mar. Pet. Geol. 66, 653-659. https://doi.org/10.1016/j.marpetgeo.2015.07.006

Dondurur, D., Küçük, H.M., Çifçi, G., 2013. Quaternary mass wasting on the western Black Sea margin, offshore of Amasra. Glob. Planet. Change 103, 248-260. https://doi.org/10.1016/j.gloplacha.2012.05.009

Ecker, C., Dvorkin, J., Nur, A.M., 2000. Estimating the amount of gas hydrate and free gas from marine seismic data. Geophysics 65, 565-573. https://doi.org/10.1190/1.1444752

Egorov, V.N., Artemov, Y.G., Gulin, S.B., Polikarpov, G., 2011. Methane seeps in the Black Sea: discovery , quantification and environmental assessment. J. Black Sea/Mediterranean Environ. 17, 171-185.

Egorov, V.N., Polikarpov, G.G., Gulin, S.B., Artemov, Y.G., Stokozov, N.A., Kostova, S.K., 2003. Presentday views on the environment-forming and ecological role of the Black Sea methane gas seeps. Mar. Ecol. J. 2, 5-26.

Elger, J., Berndt, C., Rüpke, L., Krastel, S., Gross, F., Geissler, W.H., 2018. Submarine slope failures due to pipe structure formation. Nat. Commun. 9, 715. https://doi.org/10.1038/s41467-018-03176-1

Feldman, H.R., Lericolais, G., Dennielou, B., 2017. Exercise 10.2 - High-Resolution Seismic Stratigraphy of the Danube Fan in the Black Sea, in: Sequence Stratigraphy of Siliciclastic Systems, SEPM Concepts in Sedimentology and Paleontology \#9. SEPM (Society for Sedimentary Geology).

Flood, R.D., Manley, P.L., Kowsmann, R.O., Appi, C.J., Pirmez, C., 1991. Seismic Facies and Late Quaternary Growth of Amazon Submarine Fan, in: Weimer, P., Link, M.H. (Eds.), Seismic Facies and Sedimentary Processes of Submarine Fans and Turbidite Systems. Springer New York, New York, NY, pp. 415-433. https://doi.org/10.1007/978-1-4684-8276-8_23

Fraser, D.R.A., Gorman, A.R., Pecher, I.A., Crutchley, G.J., Henrys, S.A., 2016. Gas hydrate accumulations related to focused fluid flow in the Pegasus Basin, southern Hikurangi Margin, New Zealand. Mar. Pet. Geol. 77, 399-408. https://doi.org/10.1016/j.marpetgeo.2016.06.025 
Gay, A., Lopez, M., Berndt, C., Séranne, M., 2007. Geological controls on focused fluid flow associated with seafloor seeps in the Lower Congo Basin. Mar. Geol. 244, 68-92. https://doi.org/10.1016/j.margeo.2007.06.003

Gay, A., Lopez, M., Cochonat, P., Seranne, M., Levache, D., Sermondadaz, G., 2006. Isolated seafloor pockmarks linked to BSRs, fluid chimneys, polygonal faults and stacked Oligocene-Miocene turbiditic palaeochannels in the Lower Congo Basin. Mar. Geol. 226, 25-40. https://doi.org/DOI 10.1016/j.margeo.2005.09.018

Gillet, H., Lericolais, G., Rehault, J.-P., Dinu, C., 2003. La stratigraphie oligo-miocène et la surface d'érosion messinienne en mer Noire, stratigraphie sismique haute résolution. Comptes Rendus Geosci. 335, 907-916. https://doi.org/10.1016/j.crte.2003.08.008

Golmshtok, A.Y., Zonenshain, L.., Terekhov, A.., Shainurov, R.., 1992. Age, thermal evolution and history of the Black Sea Basin based on heat flow and multichannel reflection data. Tectonophysics 210, 273-293. https://doi.org/10.1016/0040-1951(92)90326-2

Gorman, A.R., Holbrook, W.S., Hornbach, M.J., Hackwith, K.L., Lizarralde, D., Pecher, I., 2002. Migration of methane gas through the hydrate stability zone in a low-flux hydrate province. Geology 30, 327. https://doi.org/10.1130/0091-7613(2002)030<0327:MOMGTT>2.0.CO;2

Greinert, J., Artemov, Y., Egorov, V., De Batist, M., McGinnis, D., 2006. 1300-m-high rising bubbles from mud volcanoes at $2080 \mathrm{~m}$ in the Black Sea: Hydroacoustic characteristics and temporal variability. Earth Planet. Sci. Lett. 244, 1-15. https://doi.org/10.1016/j.epsl.2006.02.011

Handwerger, A.L., Rempel, A.W., Skarbek, R.M., 2017. Submarine landslides triggered by destabilization of high-saturation hydrate anomalies. Geochemistry, Geophys. Geosystems 18, 2429-2445. https://doi.org/10.1002/2016GC006706

Heeschen, K.U., Haeckel, M., Klaucke, I., Ivanov, M.K., Bohrmann, G., 2011. Quantifying in-situ gas hydrates at active seep sites in the eastern Black Sea using pressure coring technique. Biogeosciences 8, 3555-3565. https://doi.org/10.5194/bg-8-3555-2011

Heggland, R., 2005. Using gas chimneys in seal integrity analysis: a discussion based on case histories., in: Boult, P., Kaldi, J. (Eds.), Evaluating Fault and Cap Rock Seals. Vol. 2. AAPG, Hedberg Series, pp. 237-245.

Ho, S., Cartwright, J.A., Imbert, P., 2012. Vertical evolution of fluid venting structures in relation to gas flux, in the Neogene-Quaternary of the Lower Congo Basin, Offshore Angola. Mar. Geol. 332-334, 40-55. https://doi.org/10.1016/j.margeo.2012.08.011

Hornbach, M.J., Holbrook, W.S., Gorman, A.R., Hackwith, K.L., Lizarralde, D., Pecher, I., 2003. Direct seismic detection of methane hydrate on the Blake Ridge. Geophysics 68, 92-100. https://doi.org/10.1190/1.1543196

Horozal, S., Bahk, J.-J., Urgeles, R., Kim, G.Y., Cukur, D., Kim, S.-P., Lee, G.H., Lee, S.H., Ryu, B.-J., Kim, J.H., 2017. Mapping gas hydrate and fluid flow indicators and modeling gas hydrate stability zone (GHSZ) in the Ulleung Basin, East (Japan) Sea: Potential linkage between the occurrence of mass failures and gas hydrate dissociation. Mar. Pet. Geol. 80, 171-191. https://doi.org/10.1016/j.marpetgeo.2016.12.001

Judd, A., Hovland, M., 2007. Seabed Fluid Flow: The Impact on Geology, Biology and the Marine Environment. Cambridge University Press, Cambridge, UK.

Karstens, J., Berndt, C., 2015. Seismic chimneys in the Southern Viking Graben - Implications for palaeo fluid migration and overpressure evolution. Earth Planet. Sci. Lett. 412, 88-100. 
Ker, S., Riboulot, V., 2015. GHASS Cruise Report, Ifremer. Ifremer, Brest, France.

696

697

698

699

700

701

702

703

704

705

706

707

708

709

710

711

712

Kessler, J.D., Reeburgh, W.S., Southon, J., Seifert, R., Michaelis, W., Tyler, S.C., 2006. Basin-wide estimates of the input of methane from seeps and clathrates to the Black Sea. Earth Planet. Sci. Lett. 243, 366-375. https://doi.org/10.1016/j.epsl.2006.01.006

Khosharay, S., Varaminian, F., 2013. Modeling interfacial tension of $(\mathrm{CH} 4+\mathrm{N} 2)+\mathrm{H} 2 \mathrm{O}$ and $(\mathrm{N} 2+\mathrm{CO} 2)+\mathrm{H} 2 \mathrm{O}$ systems using linear gradient theory. Korean J. Chem. Eng. 30, 724-732. https://doi.org/10.1007/s11814-012-0187-9

Klaucke, I., Sahling, H., Weinrebe, W., Blinova, V., Bürk, D., Lursmanashvili, N., Bohrmann, G., 2006. Acoustic investigation of cold seeps offshore Georgia, eastern Black Sea. Mar. Geol. 231, 51-67. https://doi.org/10.1016/j.margeo.2006.05.011

Koch, S., Berndt, C., Bialas, J., Haeckel, M., Crutchley, G., Papenberg, C., Klaeschen, D., Greinert, J., 2015. Gas-controlled seafloor doming. Geology 43, 571-574. https://doi.org/10.1130/G36596.1

Konerding, P., 2008. Quaternary tectonics and seismic stratigraphy of the western Black Sea shelf. PhD Thesis. University of Hamburg.

Kossel, E., Bigalke, N., Piñero, E., Haeckel, M., 2013. The SUGAR Toolbox - A library of numerical algorithms and data for modelling of gas hydrate systems and marine environments. Bremerhaven, Germany. https://doi.org/10013/epic.41749.d002

Kutas, R.I., Paliy, S.I., Rusakov, O.M., 2004. Deep faults, heat flow and gas leakage in the northern Black Sea. Geo-Marine Lett. 24, 163-168. https://doi.org/10.1007/s00367-004-0172-3

Lericolais, G., Bourget, J., Popescu, I., Jermannaud, P., Mulder, T., Jorry, S., Panin, N., 2013. Late Quaternary deep-sea sedimentation in the western Black Sea: New insights from recent coring and seismic data in the deep basin. Glob. Planet. Change 103, 232-247. https://doi.org/10.1016/j.gloplacha.2012.05.002

Li, A., Davies, R.J., Yang, J., 2016. Gas trapped below hydrate as a primer for submarine slope failures. Mar. Geol. 380, 264-271. https://doi.org/10.1016/j.margeo.2016.04.010

Locat, J., Lee, H.J., 2002. Submarine landslides: advances and challenges. Can. Geotech. J. 39, 193-212. https://doi.org/10.1139/t01-089

Løseth, H., Gading, M., Wensaas, L., 2009. Hydrocarbon leakage interpreted on seismic data. Mar. Pet. Geol. 26, 1304-1319. https://doi.org/10.1016/j.marpetgeo.2008.09.008

Løseth, H., Wensaas, L., Arntsen, B., Hanken, N.M., Basire, C., Graue, K., 2011. 1000 m long gas blowout pipes. Mar. Pet. Geol. 28, 1040-1060. https://doi.org/10.1016/j.marpetgeo.2010.10.001

Lüdmann, T., Wong, H.K., Konerding, P., Zillmer, M., Petersen, J., Flüh, E., 2004. Heat flow and quantity of methane deduced from a gas hydrate field in the vicinity of the Dnieper Canyon, northwestern Black Sea. Geo-Marine Lett. 24, 182-193. https://doi.org/10.1007/s00367-004-0169-y

Maestrelli, D., lacopini, D., Jihad, A.A., Bond, C.E., Bonini, M., 2017. Seismic and structural characterization of fluid escape pipes using $3 D$ and partial stack seismic from the Loyal Field (Scotland, UK): A multiphase and repeated intrusive mechanism. Mar. Pet. Geol. 88, 489-510. https://doi.org/10.1016/j.marpetgeo.2017.08.016

Manley, P.L., Pirmez, C., Busch, W., Cramp, A., 1997. Grain-size characterization of Amazon Fan deposits and comparison to seismic facies units, in: Flood, R.D., Piper, D.J.W., Klaus, A., Peterson, L.C. (Eds.), 
Martin, R.E., Yanko-Hombach, V., 2011. Rapid Holocene sea-level and climate change in the Black Sea: An evaluation of the Balabanov sea-level curve, in: Geological Society of America Special Papers. Geological Society of America, pp. 51-58. https://doi.org/10.1130/2011.2473(04)

Max, M.D., Johnson, A.H., 2014. Hydrate petroleum system approach to natural gas hydrate exploration. Pet. Geosci. 20, 187-199. https://doi.org/10.1144/petgeo2012-049

Mazzini, A., Ivanov, M.K., Parnell, J., Stadnitskaia, A., Cronin, B.T., Poludetkina, E., Mazurenko, L., Van Weering, T.C.E., 2004. Methane-related authigenic carbonates from the Black Sea: Geochemical characterisation and relation to seeping fluids. Mar. Geol. 212, 153-181. https://doi.org/10.1016/j.margeo.2004.08.001

Mclver, R.D., 1982. Role of naturally occuring gas hydrates in sediment transport. Am. Assoc. Pet. Geol. Bull. Vol. 66, 789-792.

Menard, H.W., 1955. Deep-sea channels, topography, and sedimentation. Am. Assoc. Pet. Geol. Bull. 39, 236-255.

Moscardelli, L., Wood, L., Mann, P., 2006. Mass-transport complexes and associated processes in the offshore area of Trinidad and Venezuela. Am. Assoc. Pet. Geol. Bull. 90, 1059-1088. https://doi.org/10.1306/02210605052

Moss, J.L., Cartwright, J., 2010. The spatial and temporal distribution of pipe formation, offshore Namibia. Mar. Pet. Geol. 27, 1216-1234. https://doi.org/10.1016/j.marpetgeo.2009.12.013

Mountjoy, J.J., Barnes, P.M., Pettinga, J.R., 2009. Morphostructure and evolution of submarine canyons across an active margin: Cook Strait sector of the Hikurangi Margin, New Zealand. Mar. Geol. 260, 45-68. https://doi.org/10.1016/j.margeo.2009.01.006

Mountjoy, J.J., Pecher, I.A., Henrys, S.A., Crutchley, G.J., Barnes, P.M., Plaza-Faverola, A., 2014. Shallow methane hydrate system controls ongoing, downslope sediment transport in a low-velocity active submarine landslide complex, Hikurangi Margin, New Zealand. Geochemistry Geophys. Geosystems2 15, 4137-4156. https://doi.org/10.1002/ 2014GC005379

Mulder, T., Alexander, J., 2001. The physical character of subaqueous sedimentary density flows and their deposits. Sedimentology 48, 269-299. https://doi.org/10.1046/j.1365-3091.2001.00360.x

Mulder, T., Cochonat, P., 1996. Classification of Offshore Mass Movements. SEPM J. Sediment. Res. Vol. 66, 43-57. https://doi.org/10.1306/D42682AC-2B26-11D7-8648000102C1865D

Naudts, L., Greinert, J., Artemov, Y., Staelens, P., Poort, J., Van Rensbergen, P., De Batist, M., 2006. Geological and morphological setting of 2778 methane seeps in the Dnepr paleo-delta, northwestern Black Sea. Mar. Geol. 227, 177-199. https://doi.org/10.1016/j.margeo.2005.10.005

Nicoll, G.D., 2016. Comment on "Seismic chimneys in the Southern Viking Graben - Implications for palaeo fluid migration and overpressure evolution" by Karstens and Berndt. Earth Planet. Sci. Lett. https://doi.org/10.1016/j.epsl.2015.11.038

Olaru-Florea, R., Ungureanu, C., Rainer, T.M., Turi, V., Raileanu, A., 2014. Understanding of the Petroleum System(s) of the Western Black Sea: Insights from 3-D Basin Modeling. AAPG Search and Discovery. AAPG Search Discov. 10686, 1-20.

Panin, N., Popescu, I., 2007. The northwestern Black Sea: Climatic and sea-level changes in the Late Quaternary, in: The Black Sea Flood Question: Changes in Coastline, Climate, and Human Settlement. Springer Netherlands, pp. 387-404. https://doi.org/10.1007/978-1-4020-5302-3_16 
Pape, T., Blumenberg, M., Seifert, R., Bohrmann, G., Michaelis, W., 2008. Links Between Geological Processes, Microbial Activities \& Evolution of Life, Links between Geological Processes, Microbial Activities \& Evolution of Life, Modern Approaches in Solid Earth Sciences. Springer Netherlands, Dordrecht. https://doi.org/10.1007/978-1-4020-8306-8

Peckmann, J., Reimer, A., Luth, U., Luth, C., Hansen, B.., Heinicke, C., Hoefs, J., Reitner, J., 2001. Methane-derived carbonates and authigenic pyrite from the northwestern Black Sea. Mar. Geol. 177, 129-150. https://doi.org/10.1016/S0025-3227(01)00128-1

Phrampus, B.J., Hornbach, M.J., 2012. Recent changes to the Gulf Stream causing widespread gas hydrate destabilization. Nature 490, 527-530. https://doi.org/10.1038/nature11528

Piper, D.J.W., Pirmez, C., Manley., P.L., Long, D., Flood, R.D., Normark, W.R., Showers, W., 1997. Masstransport deposits of the Amazon Fan, in: Flood, R.D., Piper, D.J., Klaus, A., Peterson, L.C. (Eds.), Proceedings of the Ocean Drilling Program, 155 Scientific Results. Ocean Drilling Program, College Station, TX, USA, pp. 109-146. https://doi.org/10.2973/odp.proc.sr.155.212.1997

Popescu, I., De Batist, M., Lericolais, G., Nouzé, H., Poort, J., Panin, N., Versteeg, W., Gillet, H., 2006. Multiple bottom-simulating reflections in the Black Sea: Potential proxies of past climate conditions. Mar. Geol. 227, 163-176. https://doi.org/10.1016/j.margeo.2005.12.006

Popescu, I., Lericolais, G., Panin, N., De Batist, M., Gillet, H., 2007. Seismic expression of gas and gas hydrates across the western Black Sea. Geo-Marine Lett. 27, 173-183. https://doi.org/10.1007/s00367-007-0068-0

Popescu, I., Lericolais, G., Panin, N., Normand, A., Dinu, C., Le Drezen, E., 2004. The Danube submarine canyon (Black Sea): morphology and sedimentary processes. Mar. Geol. 206, 249-265. https://doi.org/10.1016/j.margeo.2004.03.003

Popescu, I., Lericolais, G., Panin, N., Wong, H.., Droz, L., 2001. Late Quaternary channel avulsions on the Danube deep-sea fan, Black Sea. Mar. Geol. 179, 25-37. https://doi.org/10.1016/S00253227(01)00197-9

Popescu, S.-M., 2006. Late Miocene and early Pliocene environments in the southwestern Black Sea region from high-resolution palynology of DSDP Site 380A (Leg 42B). Palaeogeogr. Palaeoclimatol. Palaeoecol. 238, 64-77. https://doi.org/10.1016/j.palaeo.2006.03.018

Reeburgh, W.S., Ward, B.B., Whalen, S.C., Sandbeck, K.A., Kilpatrickt, K.A., Kerkhof, L.J., 1991. Black Sea methane geochemistry. Deep Sea Res. Part A. Oceanogr. Res. Pap. 38, S1189-S1210. https://doi.org/10.1016/S0198-0149(10)80030-5

Riboulot, V., Cattaneo, A., Scalabrin, C., Gaillot, A., Jouet, G., Ballas, G., Marsset, T., Garziglia, S., Ker, S., 2017. Control of the geomorphology and gas hydrate extent on widespread gas emissions offshore Romania. Bull. la Société géologique Fr. 188, 26. https://doi.org/10.1051/bsgf/2017182

Riboulot, V., Ker, S., Sultan, N., Thomas, Y., Marsset, B., Scalabrin, C., Ruffine, L., Boulart, C., Ion, G., 2018. Freshwater lake to salt-water sea causing widespread hydrate dissociation in the Black Sea. Nat. Commun. 9, 117. https://doi.org/10.1038/s41467-017-02271-z

Rollet, N., Logan, G.A., Ryan, G., Judd, A.G., Totterdell, J.M., Glenn, K., Jones, A.T., Kroh, F., Struckmeyer, H.I.M., Kennard, J.M., Earl, K.L., 2009. Shallow gas and fluid migration in the northern Arafura Sea (offshore Northern Australia). Mar. Pet. Geol. 26, 129-147. https://doi.org/10.1016/j.marpetgeo.2007.07.010

Römer, M., Sahling, H., Pape, T., Bahr, A., Feseker, T., Wintersteller, P., Bohrmann, G., 2012. Geological control and magnitude of methane ebullition from a high-flux seep area in the Black Sea-the 
Seebeck, H., Tenthorey, E., Consoli, C., Nicol, A., 2015. Polygonal faulting and seal integrity in the Bonaparte Basin, Australia. Mar. Pet. Geol. 60, 120-135. https://doi.org/10.1016/j.marpetgeo.2014.10.012

Sheriff, R.E., 2011. Encyclopedic dictionary of applied geophysics, 4th ed. Society of Exploration Geophysics, Tulsa, USA.

Starostenko, V.I., Rusakov, O.M., Shnyukov, E.F., Kobolev, V.P., Kutas, R.I., 2010. Methane in the northern Black Sea: characterization of its geomorphological and geological environments. Geol. Soc. London, Spec. Publ. 340, 57-75. https://doi.org/10.1144/SP340.5

Suess, E., 2014. Marine cold seeps and their manifestations: geological control, biogeochemical criteria and environmental conditions. Int. J. Earth Sci. 103, 1889-1916. https://doi.org/10.1007/s00531014-1010-0

Sun, Q., Alves, T., Xie, X., He, J., Li, W., Ni, X., 2017. Free gas accumulations in basal shear zones of masstransport deposits (Pearl River Mouth Basin, South China Sea): An important geohazard on continental slope basins. Mar. Pet. Geol. 81, 17-32. https://doi.org/10.1016/j.marpetgeo.2016.12.029

Thöle, H., Kuhlmann, G., Lutz, R., Gaedicke, C., 2016. Late Cenozoic submarine slope failures in the southern North Sea - Evolution and controlling factors. Mar. Pet. Geol. 75, 272-290. https://doi.org/10.1016/j.marpetgeo.2016.04.028

Vanneste, M., De Batist, M., Golmshtok, A., Kremlev, A., Versteeg, W., 2001. Multi-frequency seismic study of gas hydrate-bearing sediments in Lake Baikal, Siberia. Mar. Geol. 172, 1-21. https://doi.org/10.1016/S0025-3227(00)00117-1

Vasilev, A., Dimitrov, L., 2002. Spatial and quantitative evaluation of the Black Sea gas hydrates. Russ. Geol. Geophys. 43, 672-684.

Winguth, C., 1998. Pleistozäne Meeresspiegelschwankungen und Sedimentation im nordwestlichen Schwarzen Meer. PhD Thesis. University of Hamburg.

Winguth, C., Wong, H.K., Panin, N., Dinu, C., Georgescu, P., Ungureanu, G., Krugliakov, V. V., Podshuveit, V., 2000. Upper Quaternary water level history and sedimentation in the northwestern Black Sea. Mar. Geol. 167, 127-146. https://doi.org/10.1016/S0025-3227(00)00024-4

Winters, W.J., Waite, W.F., Mason, D.H., Gilbert, L.Y., Pecher, I.A., 2007. Methane gas hydrate effect on sediment acoustic and strength properties. J. Pet. Sci. Eng. 56, 127-135. https://doi.org/10.1016/j.petrol.2006.02.003

Wong, H.K., Panin, N., Dinu, C., Georgescu, P., Rahn, C., 1994. Morphology and post-Chaudian (Late Pleistocene) evolution of the submarine Danube fan complex. Terra Nov. 6, 502-511. https://doi.org/10.1111/j.1365-3121.1994.tb00894.x

Wong, H.K., Winguth, C., Panin, N., Dinu, C., Wollschlager, M., Georgescu, P., Ungureanu, G., Krugliakov, V. V., Podshuveit, V., 1997. The Danube and Dniepr fans, morphostructure and evolution. GeoEcoMarina 2, 77-102.

Yoneda, J., Jin, Y., Katagiri, J., Tenma, N., 2016. Strengthening mechanism of cemented hydrate-bearing sand at microscales. Geophys. Res. Lett. 43, 7442-7450. https://doi.org/10.1002/2016GL069951

Yun, T.S., Francisca, F.M., Santamarina, J.C., Ruppel, C., 2005. Compressional and shear wave velocities in uncemented sediment containing gas hydrate. Geophys. Res. Lett. 32, L10609. 
Zander, T., Choi, J.C., Vanneste, M., Berndt, C., Dannowski, A., Carlton, B., Bialas, J., 2017a. Potential impacts of gas hydrate exploitation on slope stability in the Danube deep-sea fan, Black Sea. Mar. Pet. Geol. https://doi.org/10.1016/j.marpetgeo.2017.08.010

Zander, T., Haeckel, M., Berndt, C., Chi, W.-C., Klaucke, I., Bialas, J., Klaeschen, D., Koch, S., Atgın, O., 2017b. On the origin of multiple BSRs in the Danube deep-sea fan, Black Sea. Earth Planet. Sci. Lett. 462, 15-25. https://doi.org/10.1016/j.epsl.2017.01.006 